\title{
4. NEOGENE DIATOM BIOSTRATIGRAPHY OF THE ICELAND SEA SITE 907¹
}

\author{
Nalân Koç ${ }^{2}$ and Reed P. Scherer ${ }^{3}$
}

\begin{abstract}
Sediments recovered during Ocean Drilling Program Leg 151 at Site 907 from the Iceland Plateau have good recovery and a pristine paleomagnetic record. Well-preserved diatoms are present throughout the middle Miocene to upper Pliocene interval and in the Holocene of Site 907 . The stratigraphic occurrence of diatom species are studied to constrain their ranges. Thirty-two diatom events are observed and given absolute age estimates through direct correlation to the established paleomagnetic stratigraphy of Site 907. Many of these species are either endemic to the Norwegian-Greenland Sea or have diachronous occurrences as compared with other high-latitude areas. However, the first occurrence of Denticulopsis praedimorpha and the last occurrence of Proboscia praebarboi appear to be roughly isochronous between the North Pacific and the Iceland Sea. The 32 diatom events are used to establish 11 biostratigraphic intervals for the Iceland Plateau area.
\end{abstract}

\section{INTRODUCTION}

The Norwegian-Greenland Sea was a region of high biosiliceous productivity until the onset of Northern Hemisphere glaciations during the late Miocene. Diatoms are the most abundant microfossil group preserved in sediments of Paleogene and early to mid-Neogene age. Diatom species through the Cenozoic show very rapid evolution, which makes it possible to establish a high-resolution biostratigraphy for the area. For these reasons, diatoms have great potential to be used as biostratigraphic markers in this area. However, most of the fossil diatom species of the Norwegian-Greenland Sea are endemic to the area. Therefore, it is not possible to use the established North Atlantic diatom biostratigraphy (Baldauf, 1984, 1987). It is also problematic to use the established high-latitude Southern Ocean and Pacific Ocean diatom biostratigraphies because of strong possibilities of diachroneity between datum levels. Therefore, it is of great importance to establish a good diatom biostratigraphy for the Norwegian-Greenland Sea.

So far there have been three Deep Sea Drilling Program (DSDP) and Ocean Drilling Program (ODP) cruises (Legs 38, 104, and 151) to the Norwegian-Greenland Sea. The existing diatom biostratigraphy for the area is based upon the DSDP Leg 38 material (Dzinoridze et al., 1978; Schrader and Fenner, 1976). This biostratigraphy is very incomplete for the following reasons: (1) Since DSDP Leg $38 \mathrm{em}-$ ployed rotary drilling and discontinuous coring for most of the sites, the recovery was very poor, and is today described as spot-coring; (2) as a result, the first and last appearances of species cannot be located with enough precision; (3) there is no paleomagnetic stratigraphy to provide ages to the diatom events. The Norwegian Sea diatom zonations proposed by Schrader and Fenner (1976) are considered imprecise (Eldholm, Thiede, Taylor, et al., 1987) and difficult to use because they used multiple diagnostic species which have rare and sporadic occurrences for defining zonal boundaries. However, the diatom studies of Schrader and Fenner (1976) and Dzinoridze et al. (1978) have been pioneering studies in documenting the diatom species of the Norwegian-Greenland Sea. The diatom zones proposed by

'Thiede, J., Myhre, A.M., Firth, J.V., Johnson, G.L., and Ruddiman, W.F. (Eds.), 1996. Proc. ODP, Sci. Results, 151: College Station, TX (Ocean Drilling Program).

2Department of Geology, University of Bergen, Allegaten 41, N-5007 Bergen, Norway. Nalan.Koc@geol.uib.no

Institute of Earth Sciences, Uppsala University, Norbyvägen 18B. S-752 36 Uppsala, Sweden.
Dzinoridze et al. (1978) are also of limited value because the zones span long time intervals and are mainly based on species from the genus Denticulopsis.

The Leg 104 sites on the Vøring Plateau were drilled with the advanced piston corer (APC) with high recovery and good sample quality. However, the Neogene sequences from Leg 104 are incomplete, owing to the occurrence of several poorly defined hiatuses. The $\mathrm{Pa}-$ leogene intervals of these sites are either missing or seriously altered by diagenesis (Eldholm, Thiede, Taylor, et al., 1987). No diatom zonation has been established for the ODP Leg 104 material from the Vøring Plateau. The existing information about diatoms from these cores comes from the low-resolution on-board studies and diatom species abundance studies of Bodén (1992) from Holes 642B, 642C, and $644 \mathrm{~A}$. Since the paleomagnetic signal of sediments older than Pliocene age have been extremely hard to interpret in Leg 104 holes, there is only a coarse relative stratigraphy and the timing of the occurrences of studied species remains uncertain.

The Leg 151 sites were drilled with APC and XCB with very high recovery and good sample quality. Rich diatom horizons were recovered in Sites 907, 908, and 913. Sites 908 and 913 contain Paleogene biosiliceous sediments. Biostratigraphic and paleoceanographic analysis of Paleogene sediments of Leg 151 can be found in Scherer and Koç (this volume). Site 907 is located on the Iceland Plateau. The crust at this site is either of Anomaly 5B age, between 14 and $15 \mathrm{Ma}$ (Vogt et al., 1980), or of Anomaly 6B age, between 22 and $24 \mathrm{Ma}$ (Talwani and Eldholm, 1977), depending on the existence of an extinct intermediate axis on the eastern Iceland Plateau. Hole 907A has a rich diatom flora and a pristine paleomagnetic record that extends back to middle middle Miocene. The purpose of this study is to take the first steps in establishing a detailed and reliable Neogene diatom biostratigraphy for the Nordic Seas by assigning absolute ages to the Neogene diatom events of Hole 907A through direct correlation to the paleomagnetic stratigraphy.

\section{METHODS}

All core-catcher samples recovered on Leg 151 were processed during the cruise. Later on shore at least one additional sample from each core section $(1.5 \mathrm{~m})$ and the core-catcher samples were analyzed for their diatom content. Approximately 1-2 g of each dry sample was placed in a $250-\mathrm{ml}$ beaker and 10 drops of $37 \% \mathrm{HCl}$ was added. After waiting for at least 15 minutes for the reaction to stop, 10 drops of $30 \%$ hydrogen peroxide were added. The sample was gently heat- 
ed until the liquid became light yellow. The acidity of the sample was diluted by centrifuging it with distilled water until a $\mathrm{pH}$ of 7 was achieved. Quantitative slides of acid-cleaned material were examined at $400 \times$ for relative diatom abundances. Assessment of total diatom abundance was qualitative. Diatoms were recorded as abundant (A) if six or more specimens were present in one field of view at $400 \times$, common $(\mathrm{C})$ if one to five specimens occurred in one field of view, few (F) if one to four specimens occurred in five fields of view, and rare $(\mathrm{R})$ if one to ten specimens occurred per horizontal traverse.

Qualitative estimates of abundance of individual taxa are based on the number of specimens observed per field of view at $400 \times$. Species were recorded as abundant (A) if two or more specimens were present in one field of view, common (C) if one to five specimens were observed per five fields of view, few (F) if two to ten specimens were observed per horizontal traverse, rare $(R)$ if one specimen was observed per horizontal traverse, and trace (T) if only fragments of the specimen were observed.

Diatom preservation was recorded as good $(\mathrm{G})$ when both finely silicified and heavily robust forms were present and no significant alteration of the frustules other than minor fragmentation was observed, moderate $(M)$ when the assemblage showed moderate breakage and slight dissolution, and poor $(\mathrm{P})$ when finely silicified forms were rare or absent, and the assemblage was dominated by robust forms and fragments.

\section{NEOGENE ICELAND SEA DIATOM INTERVALS}

The Neogene Iceland Sea diatom intervals proposed in this study are based on observations of ranges of diatom species from Hole $907 \mathrm{~A}$ and represent a time interval spanning the middle middle Miocene to the Present (Table 1, Fig. 1).

\section{Time Scale}

The geomagnetic polarity time scale used here is that of Cande and Kent (1992). Correlation of the paleomagnetic record of Hole $907 \mathrm{~A}$ to the geomagnetic polarity time scale of Cande and Kent (1992) indicates that the sequence goes back to at least Chron C5AD (14.8 Ma; Fig. 1). However, Chrons C3B and C4A seem to be missing from the sequence. Thus, the sequence is incomplete because of the presence of two possible unconformities between 6.7-7.2 Ma and between 8.5-9.5 Ma.

\section{Intervals}

A total of 32 diatom events are observed and given absolute age estimates through direct correlation to the established paleomagnetic stratigraphy of Hole 907A (Fig. 1, Table 2). Eleven intervals, which are correlated to the geomagnetic record of Hole 907A, are defined (Fig. 2).

\section{Coscinodiscus norwegicus Interval}

Authors. Koç and Scherer, herein.

Definition of top. FO Denticulopsis praedimorpha

Definition of base. FO Coscinodiscus norwegicus

Age. middle middle Miocene, 13.6-12.9 Ma.

Paleomagnetic correlation. The base boundary of this interval falls within Chron $\mathrm{C} 5 \mathrm{ABr}$.

Discussion and remarks. Floral elements of this interval include $R$. norwegicus, $P$. praebarboi, $T$. yabei, I. tenuis, D. hustedtii, C. norwegicus, and $T$. grunowii (Table 1). This interval correlates to the North Atlantic C. lewisianus Zone of Baldauf et al. (1987), which includes all of the above mentioned species but also A. ingens. However, the first occurrence of $A$. ingens in Hole $907 \mathrm{~A}$ is recorded above the $C$. norwegicus Interval (Figs. 1,2). This may suggest that the FO of $A$. ingens is not synchronous between the North Atlantic and the Iceland Sea. The $C$. norwegicus Interval correlates to the interval from the top part of the $D$. hyalina Zone to the top of the $C$. nicobarica Zone in the North Pacific (Barron and Gladenkov, 1995). The top of the $C$. nicobarica Zone in the North Pacific is also defined by the first occurrence of $D$. praedimorpha and has an age of $\sim 12.8 \mathrm{Ma}$, which correlates well with the Hole 907A age of $12.9 \mathrm{Ma}$.

The first common occurrence (FCO) of $D$. hustedtii is recorded in Sample 151-907-19H-CC within Chron C5AB (Table 1, Fig. 1). This event is no older than Chron C5AB in the North Pacific (Barron and Gladenkov, 1995). The near coincidence of this datum with the first occurrence of T. grunowii (Sample 151-907-20H-2) is also seen in the North Pacific (Barron, 1980; Barron and Keller, 1983), equatorial Pacific (Barron, 1985) and at Norwegian Sea Site 338 (Schrader and Fenner, 1976) and can be an important datum for inter-regional correlation.

\section{Actinocyclus ingens Interval}

Authors. Koç and Scherer, herein.

Definition of top. FO Synedra pulchella

Definition of base. FO Denticulopsis praedimorpha

Age. middle Miocene, 12.9-12.0 Ma.

Paleomagnetic correlation. The base boundary of this interval falls within Chron C5AAn.

Discussion and remarks. The first occurrence of $A$. ingens is recorded right above the base of this interval (Fig. 1). The first occurrence of $N$. donahuensis is recorded within this interval. This interval correlates in the North Pacific to D. praedimorpha Zone (Barron and Gladenkov, 1995) and in the North Atlantic to C. gigas var. diorama Zone (Baldauf et al., 1987).

\section{Nitzschia donahuensis Interval}

Authors. Koç and Scherer, herein.

Definition of top. LO Nitzschia donahuensis

Definition of base. FO Synedra pulchella

Age. middle Miocene, 12.0-11.7 Ma.

Paleomagnetic correlation. The base boundary of this interval falls within the base of Chron C5Anln.

Discussion and remarks. This interval is characterized by the abundant to common occurrence of both Synedra pulchella and Nitzschia donahuensis. Both of these species have very short ranges and distinct taxonomic morphologies, making them very promising as biostratigraphic markers in the Norwegian-Greenland Sea (Table 1, Fig. 1).

\section{Synedra pulchella Interval}

Authors. Koç and Scherer, herein.

Definition of top. LO Synedra pulchella

Definition of base. LO Nitzschia donahuensis

Age. late middle Miocene, 11.7-11.0 Ma.

Paleomagnetic correlation. The base boundary of this interval falls within Chron C5r3.

Discussion and remarks. This interval is characterized by the abundant occurrence of Synedra pulchella and the absence of Nitzschia donahuensis.

\section{Proboscia praebarboi Interval}

Authors. Koç and Scherer, herein.

Definition of top. LO Actinocyclus ingens

Definition of base. LO Synedra pulchella

Age. late late Miocene, 11.0-10.1 Ma. The last occurrence of Synedra pulchella and the base of this interval correlates to the middle/upper Miocene boundary. 
Table 1. Diatoms of Site 907.

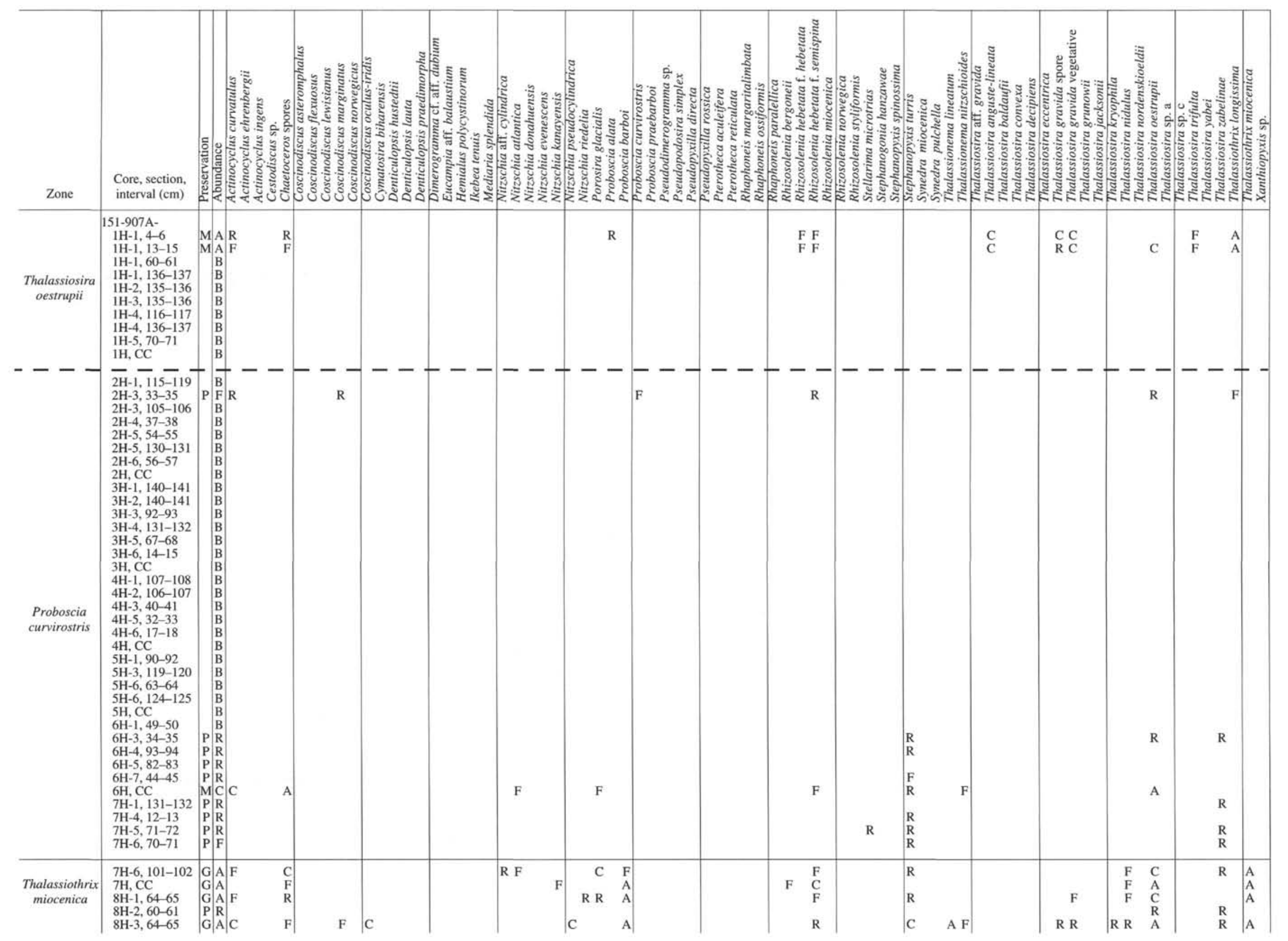




\begin{tabular}{|c|c|c|c|c|c|c|c|c|c|c|c|c|c|c|c|c|c|c|c|c|c|c|c|}
\hline Zone & $\begin{array}{l}\text { Core, section, } \\
\text { interval }(\mathrm{cm})\end{array}$ & 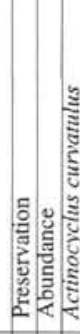 & 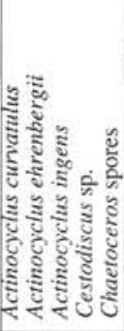 & 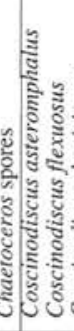 & 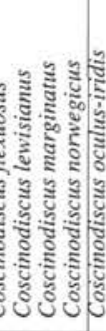 & 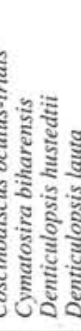 & 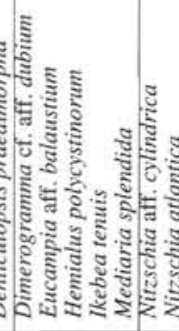 & 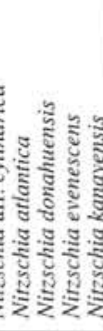 & 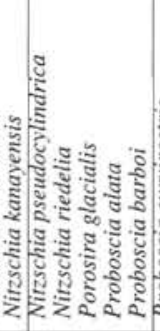 & 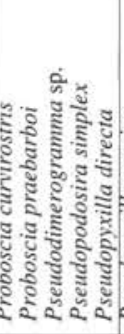 & 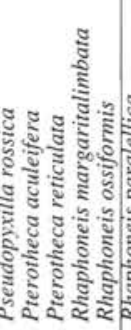 & & 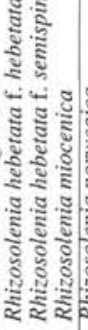 & 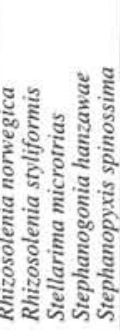 & & 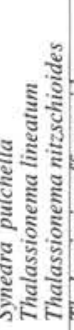 & & s & 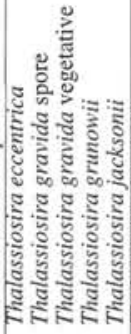 & 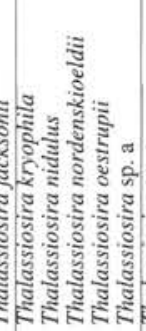 & 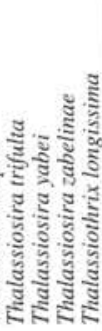 & 跣 & : \\
\hline $\begin{array}{c}\text { Thalassiothrix } \\
\text { miocenica }\end{array}$ & $\begin{array}{l}8 \mathrm{H}-4,63-64 \\
8 \mathrm{H}-5,62-63 \\
8 \mathrm{H}-6,44-45 \\
8 \mathrm{H}, \mathrm{CC} \\
9 \mathrm{H}-1,31-32 \\
9 \mathrm{H}-2,64-65\end{array}$ & \begin{tabular}{|l|l} 
& $B$ \\
& $B$ \\
& $B$ \\
$G$ & $A$ \\
$P$ & $R$ \\
$P$ & $R$ \\
$P$ & $R$
\end{tabular} & & $\mathrm{~A}$ & F & & & $R$ & $\mathrm{~F} C \mathrm{FCF}$ & $\mathrm{F}$ & & & $\mathrm{R}$ & $\begin{array}{r}\mathrm{R} \mathrm{C} \\
\mathrm{F}\end{array}$ & C & C R & & C R & & C A & R & C & \\
\hline $\begin{array}{c}\text { Thalassiosira } \\
\text { jacksonii }\end{array}$ & $\begin{array}{l}9 \mathrm{H}-3,103-104 \\
9 \mathrm{H}-4,62-63 \\
9 \mathrm{H}-5,63-64 \\
9 \mathrm{H}-6,126-127 \\
9 \mathrm{H}-7,59-60 \\
9 \mathrm{H}, \mathrm{CC} \\
10 \mathrm{H}-1,134-135 \\
10 \mathrm{H}-3,98-100 \\
10 \mathrm{H}-4,143-144 \\
10 \mathrm{H}-5,102-103 \\
10 \mathrm{H}-6,102-103\end{array}$ & \begin{tabular}{|c|c|c}
$\mathrm{M}$ & $\mathrm{R}$ \\
$\mathrm{G}$ & $\mathrm{A}$ \\
$\mathrm{G}$ & $\mathrm{B}$ \\
$\mathrm{G}$ & $\mathrm{A}$ \\
$\mathrm{M}$ & $\mathrm{C}$ \\
$\mathrm{P}$ & $\mathrm{R}$ \\
$\mathrm{G}$ & $\mathrm{C}$ \\
$\mathrm{G}$ & $\mathrm{A}$ \\
4 & $\mathrm{~B}$ \\
3 & $\mathrm{~B}$ \\
3 & $\mathrm{~B}$ & \\
\end{tabular} & $\begin{array}{ll} & \mathrm{A} \\
& \mathrm{C} \\
\mathrm{R} & \mathrm{C} \\
\mathrm{F} & \mathrm{F} \\
& \mathrm{A}\end{array}$ & $\begin{array}{l}\mathrm{A} \\
\mathrm{C} \\
\mathrm{C} \\
\mathrm{F} \\
\mathrm{A}\end{array}$ & $\mathrm{F}$ & & $\begin{array}{l}\mathrm{C} \\
\mathrm{C} \\
\mathrm{R}\end{array}$ & & $\left|\begin{array}{lll}\mathrm{F} & \mathrm{C} & \mathrm{C} \\
\mathrm{C} & \mathrm{C} & \mathrm{C} \\
& & \mathrm{C} \\
& \mathrm{R} & \mathrm{A} \\
& \mathrm{F} & \mathrm{C}\end{array}\right|$ & & & & $\begin{array}{r}\mathrm{R} \\
\mathrm{F} \\
\mathrm{R} \\
\mathrm{R} \\
\mathrm{R}\end{array}$ & $\begin{array}{c}F^{R} \\
F \\
F \\
\text { R C A }\end{array}$ & $\begin{array}{l}\mathrm{C} \\
\mathrm{R} \\
\mathrm{R}\end{array}$ & $\begin{array}{l}\text { A R } \\
F \\
\text { A } \\
F \\
\text { R }\end{array}$ & & \begin{tabular}{r|r}
$\mathrm{F}$ & $\mathrm{A}$ \\
$\mathrm{FF}$ & $\mathrm{A}$
\end{tabular} & $\begin{array}{ll}\mathrm{R} & \\
\mathrm{A} & \\
\mathrm{A} & \mathrm{R}\end{array}$ & \begin{tabular}{c|}
$\mathrm{R}$ \\
$\mathrm{A}$ \\
$\mathrm{A}$ \\
$\mathrm{C}$ \\
$\mathrm{A}$ \\
$\mathrm{A}$ \\
$\mathrm{F}$ \\
$\mathrm{C}$
\end{tabular} & & & \\
\hline $\begin{array}{c}\text { Proboscia } \\
\text { barboi }\end{array}$ & $\begin{array}{l}10 \mathrm{H}, \mathrm{CC} \\
11 \mathrm{H}-1,133-134 \\
11 \mathrm{H}-2,11-12 \\
11 \mathrm{H}-2,21-22 \\
11 \mathrm{H}-3,31-32 \\
11 \mathrm{H}-4,32-33 \\
11 \mathrm{H}-4,64-66 \\
11 \mathrm{H}-5,142-143 \\
11 \mathrm{H}-6,106-107 \\
11 \mathrm{H}-7,52-53 \\
11 \mathrm{H}, \mathrm{CC} \\
12 \mathrm{H}-3,84-86 \\
12 \mathrm{H}-4,14-16 \\
12 \mathrm{H}-4,40-41\end{array}$ & 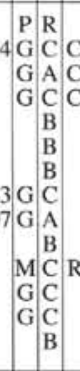 & $\begin{array}{ll} & \\
\mathrm{C} \\
\mathrm{C} \\
\mathrm{C}\end{array}$ & $\begin{array}{ll}\mathrm{R} & \\
\mathrm{R} & \\
\mathrm{C} & \\
\mathrm{C} & \\
\mathrm{C} & \end{array}$ & $\begin{array}{l}\mathrm{C} \\
\mathrm{C} \\
\mathrm{F}\end{array}$ & & $\begin{array}{l}\mathrm{R} \\
\mathrm{R}\end{array}$ & & 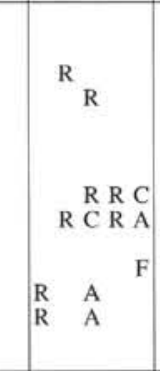 & $\mathrm{R}$ & & & $\begin{array}{l}\mathrm{C} R \\
\mathrm{FR} \\
\mathrm{C} \\
\mathrm{C} \\
\mathrm{R} \\
\mathrm{R}\end{array}$ & $\begin{array}{l}{ }_{\mathrm{R}} \\
\\
\\
\mathrm{F} \mathrm{R} \\
\mathrm{F} \mathrm{F} \\
\mathrm{R} \text { A } \\
\mathrm{C} \\
\mathrm{C}\end{array}$ & F & $\begin{array}{l}\text { A } \\
\text { C } \\
\text { C } \\
\text { C } \\
\text { C }\end{array}$ & & $\begin{array}{ll}\mathrm{C} & \\
\mathrm{C} & \mathrm{F} \\
\mathrm{C} & \mathrm{F}\end{array}$ & R & $\begin{array}{l}\mathrm{R} \\
\mathrm{F} \\
\mathrm{F}\end{array}$ & & \begin{tabular}{l|l}
$C$ & $F$ \\
$C$ & $F$
\end{tabular} & \\
\hline $\begin{array}{c}\text { Denticulopsis } \\
\text { hustedtii }\end{array}$ & $\begin{array}{l}12 \mathrm{H}-5,25-26 \\
12 \mathrm{H}-5,70-72 \\
12 \mathrm{H}-\mathrm{T}, 134-136 \\
12 \mathrm{H}-6,124-126 \\
12 \mathrm{H}-7,62-64 \\
12 \mathrm{H}, \mathrm{CC} \\
13 \mathrm{H}-4,40-41 \\
13 \mathrm{H}-6,40-41 \\
13 \mathrm{H}, \mathrm{CC}\end{array}$ & \begin{tabular}{|ll|l}
$\mathrm{M}$ & $\mathrm{A}$ \\
$\mathrm{G}$ & $\mathrm{A}$ \\
$6 \mathrm{G}$ & $\mathrm{A}$ \\
$6 \mathrm{G}$ & $\mathrm{A}$ \\
$\mathrm{G}$ & $\mathrm{C}$ \\
$\mathrm{G}$ & $\mathrm{A}$ \\
$\mathrm{G}$ & $\mathrm{A}$ \\
$\mathrm{G}$ & $\mathrm{C}$ \\
$\mathrm{G}$ & $\mathrm{A}$ \\
$\mathrm{G}$ & $\mathrm{A}$ & $\mathrm{R}$
\end{tabular} & 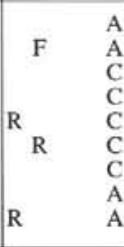 & $\begin{array}{l}A \\
A \\
C \\
C \\
C \\
C \\
C \\
\text { A } \\
\text { A }\end{array}$ & 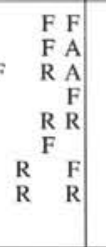 & $\begin{array}{l}\mathrm{R}^{\mathrm{C}} \\
\mathrm{F} \\
\mathrm{F} \\
\mathrm{A}\end{array}$ & $\begin{array}{ll}\mathrm{F} & \mathrm{F} \\
\mathrm{R} & \mathrm{R} \\
\mathrm{R} & \mathrm{F} \\
\mathrm{R} & \\
\mathrm{R} & \\
\mathrm{R} & \mathrm{F} \\
\mathrm{R} & \mathrm{C} \\
& \mathrm{R}\end{array}$ & $\mathrm{R}$ & $\begin{array}{lll} & F & R \\
R & & R \\
R & & \\
& R & \\
R & R & \\
F & R & \\
& R & R\end{array}$ & $\begin{array}{l}\mathrm{R} \\
\mathrm{R}\end{array}$ & $\mathrm{R}$ & 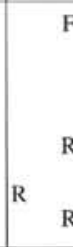 & $\begin{array}{l}\mathrm{FF} \\
\mathrm{A} \\
\mathrm{C} \\
\mathrm{C} \\
{ }_{\mathrm{R}} \\
{ }_{\mathrm{R}} \\
{ }_{\mathrm{F}} \\
{ }_{\mathrm{R}}\end{array}$ & $\begin{array}{rl} & \mathrm{C} \\
\mathrm{R} & \mathrm{R} \\
\mathrm{R} & \mathrm{C} \\
\mathrm{R} & \mathrm{F} \\
\mathrm{R} & \mathrm{R} \\
\mathrm{R} & \mathrm{F} \\
\mathrm{R} & \mathrm{F} \\
\mathrm{R} & \mathrm{A} \\
\mathrm{C} & \mathrm{R}\end{array}$ & \begin{tabular}{|l}
$\mathrm{R}$ \\
$\mathrm{R}$
\end{tabular} & $\begin{array}{l}\text { C } \\
\text { A } \\
\text { A } \\
\text { A } \\
\text { C } \\
\text { C } \\
\text { A } \\
\text { A }\end{array}$ & $\begin{array}{l}\mathrm{C} \\
\mathrm{R}\end{array}$ & & $\begin{array}{l}C \\
R \\
R \\
R \\
R \\
R \\
F \\
F \\
R\end{array}$ & $\mathrm{R}$ & & & \\
\hline $\begin{array}{c}\text { Proboscia } \\
\text { praebarboi }\end{array}$ & $\begin{array}{l}14 \mathrm{H}-1,39-40 \\
14 \mathrm{H}-2,78-79 \\
14 \mathrm{H}-3,72-73 \\
14 \mathrm{H}-4,72-73 \\
14 \mathrm{H}-5,78-79 \\
14 \mathrm{H}-6,73-74 \\
14 \mathrm{H}, \mathrm{CC}\end{array}$ & \begin{tabular}{l|l|l}
$\mathrm{G}$ & $\mathrm{A}$ & $\mathrm{F}$ \\
$\mathrm{G}$ & $\mathrm{A}$ & $\mathrm{B}$ \\
$\mathrm{G}$ & $\mathrm{A}$ & $\mathrm{C}$ \\
$\mathrm{G}$ & $\mathrm{A}$ & \\
$\mathrm{G}$ & $\mathrm{A}$ & \\
$\mathrm{G}$ & $\mathrm{A}$ & \\
$\mathrm{G}$ & $\mathrm{A}$ & $\mathrm{B}$
\end{tabular} & 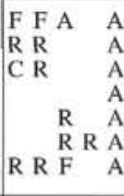 & $\begin{array}{ll}A & \\
A & R \\
A & R \\
A & R \\
A & \\
A & \\
A & \end{array}$ & \begin{tabular}{l|l}
$\mathrm{R}$ & $\mathrm{A}$ \\
& \\
$\mathrm{R}$ & \\
$\mathrm{A}$ &
\end{tabular} & $\begin{array}{ll}\mathrm{F} & \mathrm{A} \\
\mathrm{C} & \mathrm{C} \\
\mathrm{C} & \mathrm{R} \\
\mathrm{R} & \mathrm{C} \\
\mathrm{F} & \mathrm{A} \\
\mathrm{C} & \mathrm{C}\end{array}$ & $\left.\begin{array}{lll}\mathrm{R} C & \mathrm{R} \\
\mathrm{R} & \mathrm{C} \\
\mathrm{R} & \mathrm{C} \\
\mathrm{C} & \mathrm{F} \\
\mathrm{C} & \mathrm{C} \\
\mathrm{R} & \mathrm{F} \\
\mathrm{F} & \mathrm{F} \\
\mathrm{R} & \mathrm{C} R\end{array}\right|^{\mathrm{R}}$ & & $\begin{array}{ll}\text { R F F F } \\
\text { R } \\
\text { C } \\
\text { C } \\
\text { F } & \\
\text { F } & \text { R F } \\
F & F \\
& \text { C F }\end{array}$ & $\begin{array}{l}\mathrm{F} \\
\mathrm{C} \\
\mathrm{C} \\
\mathrm{F} \\
\mathrm{C} F\end{array}$ & $\begin{array}{l}\text { C } \\
\text { C F } \\
\text { R R R R } \\
\text { F } \\
\text { F R } \\
\text { F }\end{array}$ & & 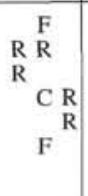 & $\begin{array}{l}\text { F R } \\
\text { F } \\
\text { R } \\
\text { R C C } \\
\text { F F } \\
\text { F R } \\
\text { C R }\end{array}$ & 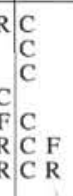 & $\begin{array}{l}\mathrm{A} \\
\mathrm{A} \\
\mathrm{A} \\
\mathrm{A} \\
\mathrm{A} \\
\mathrm{A} \\
\mathrm{A}\end{array}$ & $\begin{array}{l}\mathrm{R} \\
\mathrm{F} \\
\mathrm{C}\end{array}$ & & $\begin{array}{l}\mathrm{F} \\
\mathrm{R} \\
\mathrm{F} \\
\mathrm{F} \\
\mathrm{R} \\
\mathrm{F} \\
\mathrm{F}\end{array}$ & $\begin{array}{l}\mathrm{F} \\
\mathrm{R}\end{array}$ & $\begin{array}{l}\mathrm{R} \\
\mathrm{F} \\
\mathrm{R} \\
\mathrm{R} \\
\mathrm{R} \\
\mathrm{R}\end{array}$ & & F \\
\hline
\end{tabular}


Table 1 (continued).

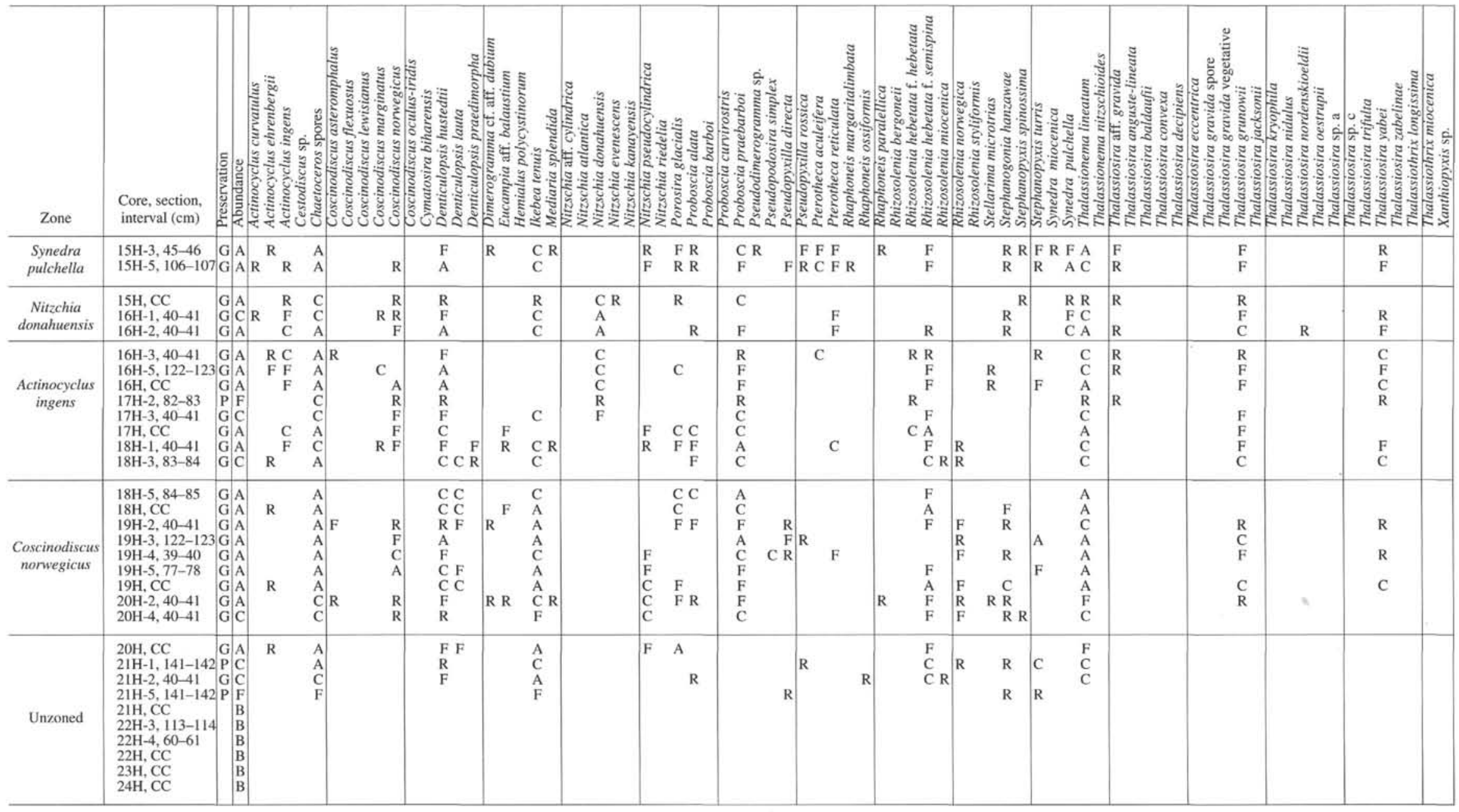

Notes: $\mathrm{B}=$ barren, $\mathrm{T}=$ trace, $\mathrm{R}=$ rare, $\mathrm{F}=$ few, $\mathrm{C}=$ common, $\mathrm{A}=$ abundant. Preservation is either poor $(\mathrm{P})$, moderate $(\mathrm{M})$, or good $(\mathrm{G})$. See $\mathrm{Appendix}$ for species list. 


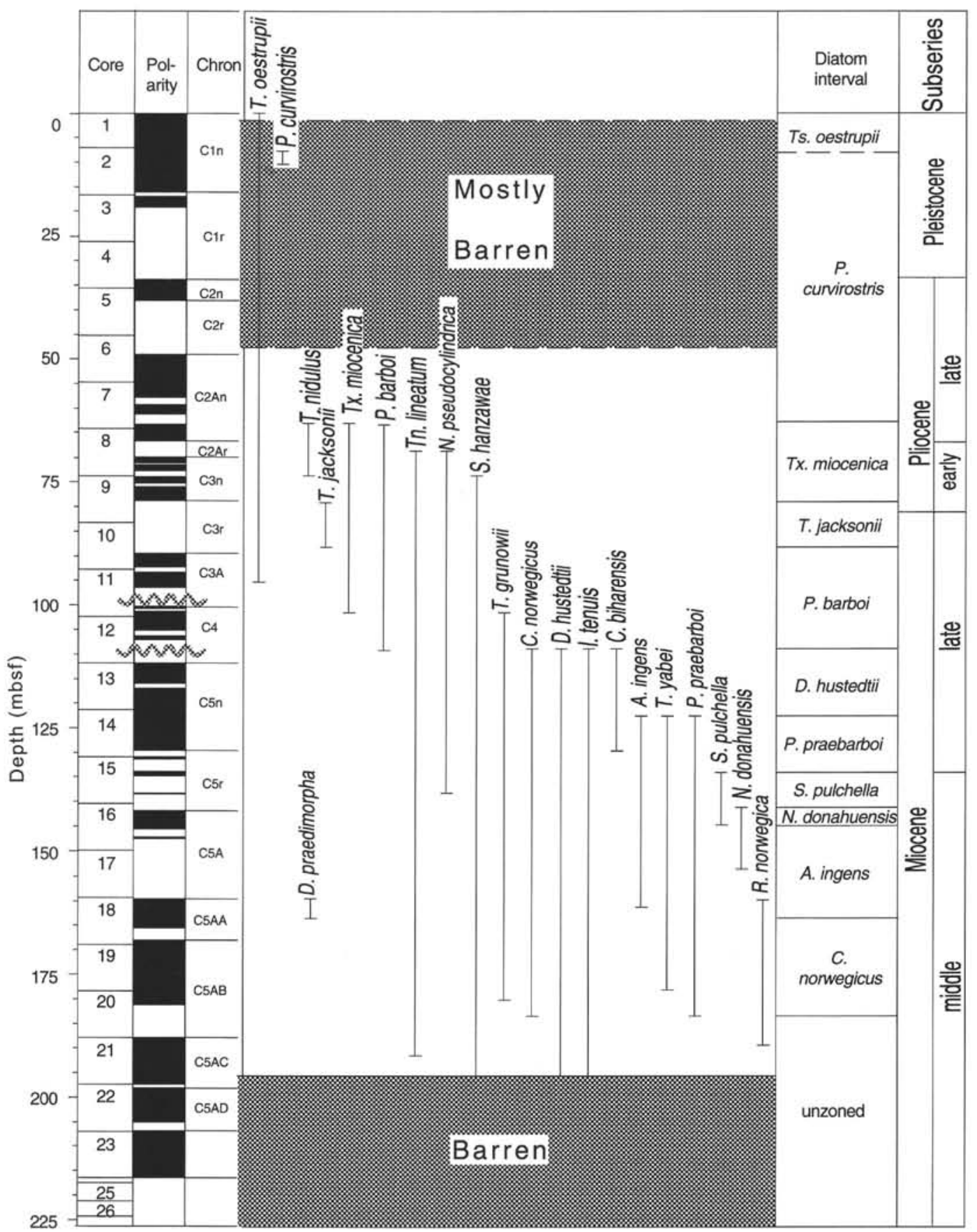

Figure 1. Stratigraphic ranges of selected diatoms and the proposed Neogene diatom intervals for Hole 907A. Plotted against core depth are cores and magnetostratigraphic chrons and subchrons. Two possible unconformities are indicated by wavy lines.

Paleomagnetic correlation. The base boundary of this interval falls within Chron $\mathrm{C} 5 \mathrm{r} 2$.

Discussion and remarks. The secondary datums for the top of this interval are the LO of $P$. praebarboi and $T$. yabei (Fig. 2). The LO of $P$. praebarboi has an estimated age of $9.5 \mathrm{Ma}$ at Site 887 in the North Pacific (Barron and Gladenkov, 1995) and an age of $10.1 \mathrm{Ma}$ at Site 907. The LO of $T$. yabei has an estimated age of 8.6-8.9 Ma in the North Pacific (Barron, 1980). In the North Pacific the LO of $P$. praebarbo $i$ and $T$. yabei falls within the $D$. dimorpha Zone. Thus, the $P$. praebarboi Interval of Site 907 can be correlated partly to the $D$. dimorpha and partly to the T. yabei Zone of the North Pacific.
The LO of Actinocyclus ingens and T. yabei occur very close together at the top of the Denticulopsis praedimorpha Zone of Baldauf (1984) within a low recovery interval in Hole 555. Accordingly, the top of the $P$. praebarboi Interval can be correlated to the top of the Denticulopsis praedimorpha Zone of Baldauf (1984). The FO of $C y$ matosira biharensis occurs at the bottom of this interval.

\section{Denticulopsis hustedtii Interval}

Authors. Koç and Scherer, herein.

Definition of top. LO Denticulopsis hustedtii 
Table 2. Specific diatom events and estimated ages for the Iceland Plateau region.

\begin{tabular}{|c|c|c|}
\hline Diatom event & $\begin{array}{c}\text { Stratigraphic } \\
\text { occurrence (mbsf) }\end{array}$ & $\begin{array}{c}\text { Estimated age } \\
(\mathrm{Ma})\end{array}$ \\
\hline LO Proboscia barboi & $63.0-63.3$ & $3.31-3.33$ \\
\hline LO Thalassiothrix miocenica & $63.0-63.3$ & $3.31-3.33$ \\
\hline LO Thalassionema lineatum & $66.4-67.9$ & $3.52-3.72$ \\
\hline LO Nitzschia pseudocylindrica & $66.4-67.9$ & $3.52-3.72$ \\
\hline LO Stephanogonia hanzawae & $72.2-73.9$ & $4.35-4.57$ \\
\hline FO Thalassiosira nidulus & $73.9-74.1$ & 4.57 \\
\hline LO Thalassiosira jacksonii & $75.9-77.8$ & $4.79-4.96$ \\
\hline FO Thalassiosira jacksonii & $87.3-89.2$ & $5.57-5.69$ \\
\hline FO Thalassiosira oestrupii & $94.5-96.1$ & $6.19-6.34$ \\
\hline LO Thalassiosira grunowii & $100.2-101.4$ & 7.25 \\
\hline FO Thalassiothrix miocenica & $101.4-102.3$ & 7.25 \\
\hline LO Coscinodiscus norwegicus & $107.2-108.6$ & $8.53-9.49$ \\
\hline LO Denticulopsis hustedrii & $107.2-108.6$ & $8.53-9.49$ \\
\hline LO lkebea tenuis & $107.2-108.6$ & $8.53-9.49$ \\
\hline LO Cymatosira biharensis & $109.0-108.6$ & $8.53-9.49$ \\
\hline FO Proboscia barboi & $109.0-109.6$ & $8.53-9.49$ \\
\hline LO Actinocyclus ingens & $121.3-121.7$ & $10.13-10.16$ \\
\hline LO Thalassiosira yabei & $121.3-121.7$ & $10.13-10.16$ \\
\hline LO Proboscia praebarboi & $121.3-121.7$ & $10.13-10.16$ \\
\hline FO Cymatosira biharensis & $129.5-130.8$ & $10.81-10.94$ \\
\hline LO Synedra pulchella & $130.8-134.3$ & $10.94-11.41$ \\
\hline FO Nitzschia pseudocylindrica & $137.9-140.3$ & $11.62-11.76$ \\
\hline LO Nitzschia donahuensis & $137.9-140.3$ & $11.62-11.76$ \\
\hline FO Synedra pulchella & $142.2-143.7$ & $11.92-12.23$ \\
\hline FO Nitzschia donahuensis & $153.2-159.3$ & $12.79-12.93$ \\
\hline LO Rhizosolenia norwegica & $159.3-159.7$ & $12.93-12.94$ \\
\hline FO Denticulopsis praedimorpha & $159.3-159.7$ & $12.93-12.94$ \\
\hline FO Actinocyclus ingens & $159.7-163.1$ & $12.94-13.25$ \\
\hline FO Thalassiosira yabei & $178.3-180.2$ & $13.48-13.52$ \\
\hline FO Thalassiosira grunowii & $180.2-183.2$ & $13.52-13.58$ \\
\hline FO Coscinodiscus norwegicus & $183.2-187.8$ & $13.58-13.67$ \\
\hline FO Proboscia praebarboi & $183.2-187.8$ & $13.58-13.67$ \\
\hline
\end{tabular}

Note: $\mathrm{FO}=$ first occurrence, $\mathrm{LO}=$ last occurrence.

Definition of base. LO Actinocyclus ingens

Age. middle late Miocene, $10.1-9.0 \mathrm{Ma}$.

Paleomagnetic correlation. The base boundary of this interval falls within Chron C5n.

Discussion and remarks. The last occurrence of Denticulopsis hustedtii occurs at an unconformity that spans the time interval 8.59.5 Ma. Therefore, the top of this zone cannot be dated precisely. In the North Pacific this event is dated to $8.4 \mathrm{Ma}$ and defines the top of the D. katayamae Zone (Barron and Gladenkov, 1995). This zone correlates to chrons C4An and C4Ar1, which are missing from Hole 907A. The D. hustedtii Interval correlates to the C. yabei Zone in the North Atlantic (Baldauf et al., 1987).

\section{Proboscia barboi Interval}

Authors. Koç and Scherer, herein.

Definition of top. FO Thalassiosira jacksonii

Definition of base. LO Denticulopsis hustedtii

Age. late Miocene, about 8.5-5.6 Ma.

Paleomagnetic correlation. The base boundary of this interval falls within an unconformity that spans the time interval 8.5-9.5 Ma.

Discussion and remarks. The first occurrence of $T$. jacksonii is dated as 5.6 Ma at Site 907 and as 5.2 Ma at Site 642 from the Vøring Plateau (Bodén, 1992). In the North Pacific this event is dated to 6.56.6 Ma (Barron and Gladenkov, 1995), which is about $1 \mathrm{Ma}$ earlier than the datums from Sites 907 and 642 .

The FO of T. oestrupii is recorded within this interval around 6.2 $\mathrm{Ma}$ (Fig. 1, Table 2). This event occurred later both in the North Pacific (5.4-5.3 Ma) (Barron and Gladenkov, 1995) and in the Southern Ocean (5.1 Ma) (Baldauf and Barron, 1991).

Secondary datums for the base of this interval are FO P. barboi and LO C. norwegicus, C. biharensis, and I. tenuis (Fig. 2). The coincidence of so many last occurrences at this level supports the presence of a hiatus at this level.

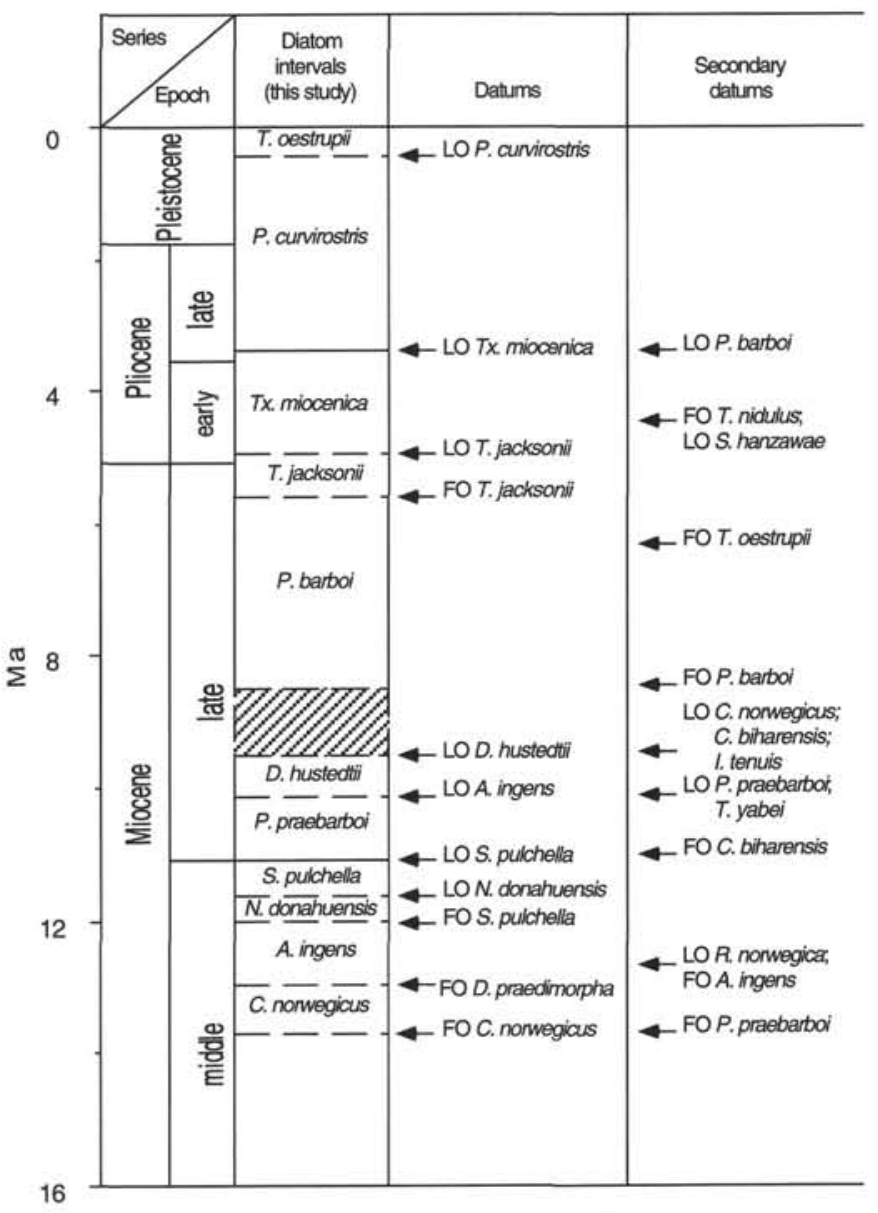

Figure 2. The Holocene through middle Miocene diatom intervals proposed in this study. The marker species delineate the individual zonal boundaries. $\mathrm{FO}=$ first occurrence, $\mathrm{LO}=$ last occurrence. Diagonal shading indicates the missing time interval.

\section{Thalassiosira jacksonii Interval}

Authors. Koç and Scherer, herein.

Definition of top. LO Thalassiosira jacksonii

Definition of base. FO Thalassiosira jacksonii

Age. latest Miocene to earliest Pliocene, 5.6-4.9 Ma. The last occurrence of Thalassiosira jacksonii and the top of this interval is right above the Miocene/Pliocene boundary.

Paleomagnetic correlation. This interval falls within Chron $\mathrm{C} 3 \mathrm{r}$.

Discussion and remarks. The interval is characterized by common to abundant $P$. barboi, $T$. jacksonii, $T$. oestrupii, and Tn. lineatum (Table 1). The short range and the abundant and consistent occurrence of $T$. jacksonii both at Site 907 and Leg 104 Vøring Plateau sites (Bodén, 1992) makes it a valuable stratigraphic marker for the Norwegian-Greenland Sea. However, a longer range (3.1-6.4 Ma) for T. jacksonii is recorded from the North Pacific (Barron, 1992).

\section{Thalassiothrix miocenica Interval}

Authors. Koç and Scherer, herein.

Definition of top. LO Thalassiothrix miocenica

Definition of base. LO Thalassiosira jacksonii

Age. early Pliocene, 4.9-3.3 Ma. The last occurrence of Thalassiosira jacksonii and the base of this zone is slightly above to the Miocene/Pliocene boundary. 
Paleomagnetic correlation. The base boundary of this interval correlates to the base of Chron $\mathrm{C} 3 \mathrm{n}$.

Discussion and remarks. This interval is characterized by common to abundant $P$. barboi, Tx. miocenica, T. oestrupii, and Tn. lineatum. The LO of Thalassiothrix miocenica is also dated to $3.3 \mathrm{Ma}$ from Site 642 at the Vøring Plateau (Bodén, 1992). The top of this interval corresponds also to the LO of $P$. barboi. The LO of Stephanogonia hanzawae, N. pseudocylindrica, Thalassionema lineatum and FO of $T$. nidulus occurs within this interval (Fig. 1). The LO of Thalassiosira jacksonii, which is dated as $4.9 \mathrm{Ma}$ at Site 907, is dated as 3.1 Ma in the North Pacific (Barron, 1992), indicating a significant diachroneity in the extinction of this species.

\section{Proboscia curvirostris Interval}

Authors. Koç and Scherer, herein.

Definition of top. LO Proboscia curvirostris

Definition of base. LO Thalassiothrix miocenica

Age. late Pliocene-Pleistocene, 3.3-? Ma.

Paleomagnetic correlation. The base boundary of this interval correlates to the boundary between Chrons C2An2/C2An 3 .

Discussion and remarks. The last occurrence of Proboscia curvirostris is within a barren zone and therefore the top of this zone cannot be precisely dated (Fig. 1). However, Baldauf (1984) extrapolated this datum to be about $0.36 \mathrm{Ma}$ in the Rockall Region of the North Atlantic. The LO of $P$. curvirostris is dated to $0.3 \mathrm{Ma}$ in the subarctic Pacific (Koizumi, 1986). The upper part of this interval correlates to the $P$. curvirostris Zone in the North Pacific (Koizumi, 1973; Barron, 1980). Most of this zone spans a barren interval at Site 907.

\section{Thalassiosira oestrupii Interval}

Authors. Koç and Scherer, herein.

Definition of top. Holocene

Definition of base. LO Proboscia curvirostris

Age. latest Pleistocene, ? $-0 \mathrm{Ma}$. The last occurrence of Proboscia curvirostris is within a barren zone and therefore the base of this interval cannot be precisely dated.

Paleomagnetic correlation. This interval boundary falls within the Brunhes chron $(\mathrm{C} 1 \mathrm{n})$.

Discussion and remarks. This interval correlates with the upper portion of the Thalassiosira oestrupii Zone of Schrader and Fenner (1976). These authors place the base of their zone immediately above the extinction of Proboscia barboi, which is recorded at 3.3 Ma right above the lower/upper Pliocene boundary at Site 907. Recent, mostly arctic floral elements, which include Proboscia alata, Rhizosolenia hebetata forma hebetata, Rhizosolenia hebetata forma semispina, Thalassiosira angustelineata, Thalassiosira gravida spore and vegetative cells, Thalassiosira oestrupii, Thalassiosira trifulta, and Thalassiothrix longissima are found in this interval (Table 1).

\section{SUMMARY}

A middle Miocene to Holocene diatom biostratigraphy for the Iceland Plateau is developed from investigation of diatom species ranges from Site 907. Many of the observed species are endemic to the Norwegian-Greenland Sea and/or show diachronous first and/or last occurrences as compared with other high-latitude regions. This causes difficulties in utilizing other already established middle- and high-latitude diatom biostratigraphies. A total of 32 diatom events are observed and given chronological estimates through direct correlation to the established paleomagnetic stratigraphy of Site 907. These events are used to establish 11 biostratigraphic intervals for this site.

\section{ACKNOWLEDGMENTS}

We are grateful to John A. Barron, Julianne Fenner, and John V. Firth for their constructive and careful reviews. We thank $O$. Tumyr for his assistance with the SEM pictures. All Leg 151 participants are thanked for a most enjoyable and productive cruise. This study is supported by grants from the Norwegian Research Foundation to N. Koç.

\section{REFERENCES}

Akiba, F., 1986. Middle Miocene to Quaternary diatom biostratigraphy in the Nankai trough and Japan trench, and modified lower Miocene through Quaternary diatom zones for middle-to-high latitudes of the North Pacific. In Kagami, H., Karig, D.E., Coulbourn, W.T., et al., Init. Repts. DSDP, 87: Washington (U.S. Govt. Printing Office), 393-481.

Akiba, F., and Yanagisawa, Y., 1986. Taxonomy, morphology and phylogeny of the Neogene diatom zonal marker species in the middle-to-high latitudes of the North Pacific. In Kagami, H., Karig, D.E., Coulbourn, W.T., et al., Init. Repts. DSDP, 87: Washington (U.S. Govt. Printing Office), 483-554.

Baldauf, J.G., 1984. Cenozoic diatom biostratigraphy and paleoceanography of the Rockall Plateau region, North Atlantic, Deep Sea Drilling Project Leg 81. In Roberts, D.G., Schnitker, D., et al., Init. Repts. DSDP, 81: Washington (U.S. Govt. Printing Office), 439-478.

1987. Diatom biostratigraphy of the middle- and high-latitude North Atlantic Ocean, Deep Sea Drilling Project Leg 94. In Ruddiman, W.F., Kidd, R.B., Thomas, E., et al., Init. Repts. DSDP, 94 (Pt. 2): Washington (U.S. Govt. Printing Office), 729-762.

Baldauf, J.G., and Barron, J.A., 1980. Actinocyclus ingens var. nodus: a new stratigraphically useful diatom of the circum-North Pacific. Micropaleontology, 26:103-110.

1982. Diatom biostratigraphy and paleoecology of the type section of the Luisian stage, central California, Micropaleontology, 28:5984.

, 1991. Diatom biostratigraphy: Kerguelen Plateau and Prydz Bay regions of the Southern Ocean. In Barron, J., Larsen, B., et al., Proc. ODP, Sci. Results, 119: College Station, TX (Ocean Drilling Program), 547-598.

Baldauf, J.G., Thomas, E., Clement, B., Takayama, T., Weaver, P.P.E., Backman, J., Jenkins, G., Mudie, P.J., and Westberg-Smith, M.J., 1987. Magnetostratigraphic and biostratigraphic synthesis, Deep Sea Drilling Project Leg 94. In Ruddiman, W.F., Kidd, R.B., Thomas, E., et al., Init. Repts. DSDP, 94 (Pt. 2): Washington (U.S. Govt. Printing Office), 1159 1205.

Barron, J.A., 1980. Lower Miocene to Quaternary diatom biostratigraphy of Leg 57, off Northeastern Japan, Deep Sea Drilling Project. In von Huene, R., Nasu, N., et al., Init. Repts. DSDP, 56, 57 (Pt. 2): Washington (U.S. Govt. Printing Office), 641-685.

1981. Late Cenozoic diatom biostratigraphy and paleoceanography of the middle-latitude eastern North Pacific, Deep Sea Drilling Project Leg 63. In Yeats, R.S., Haq, B.U., et al., Init. Repts. DSDP, 63: Washington (U.S. Govt. Printing Office), 507-538.

, 1985. Late Eocene to Holocene diatom biostratigraphy of the equatorial Pacific Ocean, Deep Sea Drilling Project Leg 85. In Mayer, L., Theyer, F., Thomas, E., et al., Init. Repts. DSDP, 85: Washington (U.S. Govt. Printing Office), 413-456.

, 1992. Neogene diatom datum levels in the equatorial and North Pacific. In Saito, T., and Ishizaki, K. (Eds.), The Centenary of Japanese Micropaleontology: Tokyo (Terra Scientific), 413-425.

Barron, J.A., and Gladenkov, A.Y., 1995. Early Miocene to Pleistocene diatom biostratigraphy of Leg 145. In Rea, D.K., Basov, I.A., Scholl, D.W., and Allan, J.F. (Eds.). Proc. ODP, Sci. Results, 145: College Station, TX (Ocean Drilling Program), 3-19.

Barron, J.A., and Keller, G., 1983. Paleotemperature oscillations in the middle and late Miocene of the northeastern Pacific. Micropaleontology, 29:150-181.

Bodén, P., 1992. Quantitative biostratigraphy of Neogene diatoms from the Norwegian Sea, North Atlantic and North Pacific. Stockholm Contrib. Geol., 42:124-202.

, 1993. Taxonomy and stratigraphic occurrence of Thalassiosira tetraoestrupii sp. nov. and related species in upper Miocene and lower 
Pliocene sediments from the Norwegian Sea, North Atlantic and northwest Pacific. Terra Nova, 5:61-75.

Brightwell, T., 1858. Remarks on the genus "Rhizosolenia" of Ehrenberg. $Q$. J. Microsc. Sci., 6:1-95.

Brun, J., 1894. Espéces nouvelles marines, fossiles ou pélagiques. Soc. Phys. Hist. Nat. Geneve Mem., 31:1-47.

Cande, S.C., and Kent, D.V., 1992. A new geomagnetic polarity time scale for the Late Cretaceous and Cenozoic. J. Geophys. Res., 97:1391713951.

Cleve, P.T., 1873. Examination of diatoms found on the surface of the Sea of Java. Bih. Sven. Vetensk.-Akad. Handl., 11:113.

1896. Diatoms from Baffin Bay and Davis Strait. Bih. Kongl. Sven. Vetensk.-Akad. Handl., 22:1-22.

1904. Plankton table for the North Sea. Bull. Cons. Perm. Intern. pour l'Explor. de la Mer, 1903-1904, 1-216.

Dzinoridze, R.N., Jousé, A.P., Koroleva-Golikova, G.S., Kozlova, G.E., Nagaeva, G.S., Petrushevskaya, M.G., and Strelnikova, N.I., 1978. Diatom and radiolarian Cenozoic stratigraphy, Norwegian Basin; DSDP Leg 38. In Talwani, M., Udintsev, G., et al., Init. Repts. DSDP, 38, 39, 40, 41 (Suppl.): Washington (U.S. Govt. Printing Office), 289-427.

Ehrenberg, C.G., 1839. Über noch jetz zahlreich lebende Tierarten der Kreidebildung und den Organismus der Polythalamien. Abh. K. Akad. Wiss. Berlin, 81-174.

1841. Über Verbreitung und Einfluss des mikroskopischen Lebens in Süd- und Nordamerika. Ber. Verhandl. K. Preuss. Akad. Wiss. Berlin, 139-144.

- $1854-1856$. Mikrogeologie, das Erden und Felsen schaffende Wirken des Unsichtbar Kleinen selbstständigen Lebens auf der Erde. Leipzig (Leopold Voss)

Eldholm, O., Thiede, J., Taylor, E., et al., 1987. Proc. ODP, Init. Repts., 104: College Station, TX (Ocean Drilling Program).

Forti, D.A., 1909. Studi per una monografia del genere Pyxilla (diatomee) e dei generi affini. Nuova Notarisia, 20:5-24.

Fryxell, G.A., and Hasle, G.R., 1972. Thalassiosira eccentrica (Ehrenberg) Cleve, T. symmetrica sp. nov., and some related Centric diatoms. J. Phycol., 8:297-317.

1977. The genus Thalassiosira: some species with a modified ring of central strutted processes. Nova Hedwigia Beih., 54:67-98.

, 1979. The genus Thalassiosira: T.trifuta sp. nova and other species with tricolumnar supports on strutted processes. Nova Hedwigia Beih., 64:13-31.

Gersonde, R., and Burckle, L.H., 1990. Neogene diatom biostratigraphy of ODP Leg 113, Weddell Sea (Antarctic Ocean). In Barker, P.F., Kennett, J.P., et al., Proc. ODP, Sci. Results, 113: College Station, TX (Ocean Drilling Program), 761-789.

Gran, H.H., 1904. Die Diatomeen der Arktischen Meere. I. Teil: Die Diatomeen des Planktons. Fauna Arct., 3:509-554.

Greville, R.K., 1866. Descriptions of new and rare diatoms. Series 20. Trans. Microsc. Soc. London, New Ser., 14:121-130.

Grunow, A., 1884. Die Diatomeen von Franz-Josefs-Land. Denkschr. Kaiserl. Akad. Wiss., Wien, Mathem.-Naturw. Classe, 48:53-112.

Hasle, G.R., 1960. Phytoplankton and ciliate species from the tropical Pacific. Skr. Nor. Vidensk. -Akad. Kl.1: Mat.-Naturvedensk. Kl., 2:150.

1965. Nitzschia and Fragilariopsis species in the light and electron microscopes. III. The genus Fragilariopsis. Skr. Nor. Vidensk. Akad. Kl. 1: Mat.-Naturvidensk Kl., 21:5-49.

Hasle, G.R., and Semina, H.J., 1987. The marine planktonic diatoms Thalassiothrix longissima and Thalassiothrix antarctica with comments on Thalassionema spp. and Synedra reinboldii. Diatom Res., 2:175-192.

Hasle, G.R., and Sims, P.A., 1986. The diatom genera Stellarima and Symbolophora with comments on the genus Actinoptychus. Br. Phycol. J., 21:97-114

Hasle, G.R., Sims, P.A., and Syvertsen, E.E., 1988. Two recent Stellerime species: S. microtrias and S. stellaris (Bacillariophyceae). Bot. Mar., $31: 195-206$

Hustedt, F., 1927-1966. Die Kieselalgen Deutschlands, Osterreichs und der Schweiz, mit Berücksichtigung der übrigen Länder Europas sowie der angrenzenden Meeresgebiete. In Rabenhorst, L. (Ed.), Kryptogamen-
Flora von Deutschland. Oesterreich und der Schweiz: Leipzig (Akademische Verlagsgesellschaft), Teil I, Sect. 1-4:1-920, 1927-1930; Teil II, Sect. 1-5:1-845, 1931-1959; Teil III, Sect. 1-3, 1-816, 1961-1966.

Jordan, R.W., and Priddle, J., 1991. Fossil members of the diatom genus Proboscia. Diatom Res., 6:55-61.

Jousé, A.P., 1959. Species novae bacillariophytorum in sedimentis fundi oceani Pacifici et Mario Ochctensis inventae. Novitates Systematicae Plantarum non Vascularum, Akad. Sci. SSSR, Inst. Botan. Nom. V. L. Komarovii, 3:12-21. 1961. Diatoms and their roles in indicating the history of oceans. Akad. Nauk. SSSR, Izv. Ser. Geogr., 2:13-20.

, 1971. Species formaeque novae et curiosae Bacillariophytorum in sedimentis fundi oceani pacifici. Novitates Systematicae Plantarum non Vascularum, Akad. Sci. SSSR, 8:12-18.

Jørgensen, E.G., 1905. The protist plankton and the diatoms in bottom samples. In Nordgaard, O. (Ed.), Hydrological and Biological Investigations in Norwegian Fjords. Bergens Mus. Skr., 49-151.

Kanaya, T., 1959. Miocene diatom assemblages from the Onnagawa Formation and their distribution in correlative formations in northeast Japan. Sci. Rep. Tohoku Univ., Ser. 2, 30:1-130.

Koizumi, I., 1973. The late Cenozoic diatoms of Sites 183-193, Leg 19 Deep Sea Drilling Project. In Creager, J.S., Scholl, D.W., et al., Init. Repts. DSDP, 19: Washington (U.S. Govt. Printing Office), 805-855.

1980. Neogene diatoms from the Emperor Seamount Chain, Leg 55, Deep Sea Drilling Project. In Jackson, E.D., Koizumi, I., et al., Init. Repts. DSDP, 55: Washington, (U.S. Govt. Printing Office), 387-400.

1986. Pliocene and Pleistocene diatom datum levels related with paleoceanography in the Northwest Pacific. Mar. Micropaleontol. $10: 309-325$

Kützing, F., 1844. Die kieselschaligen Bacillarien oder Diatomeen: Nordhausen (W. Köhne).

Mertz, D., 1966. Mikropalaeontologische und sedimentologische Untersuchung der Pisco-Formation Suedperus. Palaeontographica B, 118:1-48.

Muchina, Y.U., 1965. New species of diatoms from the bottom sediments of the equatorial region of the Pacific. Novitates Systematicae Plantarum non Vascularum, Akad. Sci. SSSR, 22-25.

Pantocsek, J., 1886-1892. Beiträge zur Kenntniss der fossilen Bacillarien Ungarns. Pt. 1, Marine Bacillarien (1886). Pt. 2, Brackwasser Bacillarien. Anhang: Analyse der Marine Depots von Bory, Bermia, Nagy-Kurtos in Ungarn; Ananio und Kusnetzk in Russland (1889): Hungary (Julius Platzko).

Peragallo, H., 1892. Monographie du genre Rhizosolenia et de quelques genres voisins. Le Diatom., 1:99-117.

Pritchard, A., 1861. History of Infusoria, Living and Fossil (4th ed.): London (Whittiker and Co.).

Rattray, J., 1890. A revision of the genus Actinocyclus Ehr. J. Quekett Microsc. Club, Ser. 2, 4:137-212.

Sancetta, C., 1982. Distribution of diatom species in surface sediments of the Bering and Okhotsk Seas. Micropaleontology, 28:221-257.

Schmidt, A., Schmidt, M., Fricke, F., Heiden, H., Müller, O., and Hustedt, F., 1874-1959: Atlas der Diatomeen-Kunde. Leipzig (R. Reisland).

Schrader, H.-J., 1973. Cenozoic diatoms from the Northeast Pacific, Leg 18. In Kulm, L.D., von Huene, R., et al., Init. Repts. DSDP, 18: Washington (U.S. Govt. Printing Office), 673-797.

1974. Revised diatom stratigraphy of the Experimental Mohole Drilling, Guadalupe Site. Proc. Calif. Acad. Sci., 39:517-562.

- 1976. Cenozoic planktonic diatom biostratigraphy of the South ern Pacific Ocean. In Hollister, C.D., Craddock, C., et al., Init. Repts. DSDP, 35: Washington (U.S. Govt. Printing Office), 605-671.

Schrader, H.-J., and Fenner, J., 1976. Norwegian Sea Cenozoic diatom biostratigraphy and taxonomy. In Talwani, M., Udintsev, G., et al., Init. Repts. DSDP, 38: Washington (U.S. Govt. Printing Office), 921-1099.

Sheshukova-Poretzkaya, V.S., 1962. New and rare Bacillariophyta from diatom series of Sakhalin Island. Uch. Zap., Igu. Ser. Biol. Nauk (Leningrad Univ.), 49:203-211. (in Russian)

1967. Neogene Marine Diatoms of Sakhalin and Kamchatka: Leningrad (Leningrad Univ.). (in Russian)

Simonsen, R., 1979. The diatom system: ideas on phylogeny. Bacillaria, 2:9-71. 
Strelnikova, N.J., 1974. Diatomei pozdnego mela. Akad. Nauk. SSSR, 1-201. Sundström, B.G., 1986. The marine diatom genus Rhizosolenia: a new approach to the taxonomy [Ph.D. dissert.]. Lund Univ., Sweden.

Talwani, M., and Eldholm, O., 1977. Evolution of the Norwegian-Greenland Sea. Geol. Soc. Am. Bull., 88:969-999.

Tempére, J., and Peragallo, H., 1907-1915. Diatomées du Monde Entier (2nd ed.): Paris (Arcachon).

Van Heurck, H., 1880-1885. Synopsis des Diatomées de Belgique. Atlas (1880-1881), Texte (1885). Anvers (Ducaju et Cie).

, 1896. A Treatise on the Diatomaceae. London (William Wesley \& Sons).

Vogt, P.R., Johnson, G.L., and Kristjansson, L., 1980. Morphology and magnetic anomalies north of Iceland. J. Geophys., 47:67-80.

Date of initial receipt: 11 July 1995

Date of acceptance: 15 December 1995

Ms 151SR-108

\section{APPENDIX}

List of Flora

Actinocyclus curvatulus Janisch, 1878 in Schmidt et al. (1874-1959): pl. 57, fig. 31; Hustedt, 1958, p. 129-130, pl. 8, fig. 81.

Actinocyclus ehrenbergii Ralfs in Pritchard, 1861: p. 834; Hustedt, 1929, p. 525, fig. 298.

Actinocyclus ingens Rattray, 1890a s. ampl.: p. 149, pl. 11, fig. 7; Baldauf and Barron, 1980, pl. 1, figs. 1-4; Baldauf and Barron, 1982, p. 68, pl. 1, figs. 6-10.

Coscinodiscus asteromphalus Ehrenberg, 1844 in Hustedt, 1930: p. 452-454, fig. 250 .

Coscinodiscus flexuosus Brun 1895 in Schrader and Fenner, 1976, pl. 15, fig. 10.

Coscinodiscus lewisianus Greville, 1866: p. 78, pl. 8, figs. 8-10; Schrader and Fenner, 1976, pl. 21, figs. 4, 6; Bodén, 1992, pl. 3, fig. 13.

Coscinodiscus marginatus Ehrenberg, 1841: p. 142; Hustedt, 1930, p. 416 fig. 223.

Coscinodiscus norwegicus Schrader in Schrader and Fenner, 1976: pl. 17, figs. $3,4 a$, b.

Coscinodiscus oculus-iridis Ehrenberg, 1839: p. 147; Hustedt, 1930, p. 454459, fig. 252.

Coscinodiscus vetustissimus Pantocsek, 1886 in Hustedt, 1930: p. 412, fig. 220; Schrader and Fenner, 1976, pl. 14, fig. 3.

Cymatosira biharensis Pantocsek, 1889: p. 66, pl. 3, fig. 42; Schrader and Fenner, 1976, pl. 8, figs. 1-5, 7; Bodén, 1992, pl. 1, fig. 5.

Denticulopsis hustedtii (Simonsen and Kanaya) Simonsen, 1979: p. 64; Baldauf and Barron, 1982, pl. 7, figs. 7, 8; Akiba and Yanagisawa, 1986, p. 488 , pl. 17 , figs. $4,5,7-23$, pl. 18 , figs. $1-10$, pl. 19, figs. $1-5$.

Denticulopsis lauta (Bailey) Simonsen, 1979: p. 64; Akiba, 1986, pl. 26, figs. 15-19; Akiba and Yanagisawa, 1986, p. 489, pl. 7, figs. 16-29, pl. 9, figs. 1-9; Bodén, 1992, pl. 3, figs. 11.

Denticulopsis praedimorpha (Akiba, 1979) Barron, 1981: p. 529, pl. 4, figs. 8-10; Akiba, 1986, pl. 27, figs. 14-26; Akiba and Yanagisawa, 1986, p. 489 , pl. 13 , figs. $1-28$, pl. 14 , figs. $1-12$; Bodén, 1992 , pl. 3, figs. $3-5$.

Dimerogramma aff. dubium Grunow in Van Heurck, 1880; Schrader and Fenner, 1976, pl. 3, figs. $12,15,16,17 \mathrm{a}$, b.

Eucampia aff. balaustium Schrader, 1976: pl. 10, figs. 15, 16

Hemiaulus polycistinorum Ehrenberg, 1854: pl. 36, figs. 43a, b; Schrader and Fenner, 1976, pl. 10, figs. 20, 21.

Ikebea tenuis (Brun) Akiba, 1986: p. 439, pl. 19, figs. 1-5; synonym: Goniothecium tenue Brun, 1894: p. 77, pl. VI, figs. 5, 6; Schrader and Fenner, 1976, pl. 6, figs. 6-10, pl. 37, figs. $6-10$.

Mediaria splendida Sheshukova-Poretzkaya, 1962: p. 210, pl. 2, fig. 5; Schrader and Fenner, 1976, pl. 8, fig. 18.

Nitzschia atlantica (Paasche) Hasle, 1965: p. 9-11, pl. 1, figs. 1-5; Schrader and Fenner, 1976, pl. 1, fig. 10.

Nitzschia donahuensis Schrader, 1976: p. 633, pl. 2, fig. 30; Gersonde and Burckle, 1990, pl. 1, figs. 16-18.

Nitzschia evenescens Schrader, 1976: p. 991, pl. 1, figs. 28, 29

Nitzschia kanayensis Schrader, 1974: p. 547, figs. 6, 23, 25, 28; Schrader and Fenner, 1976, pl. 1, figs. 21-23.

Nitzschia pseudocylindrica Schrader in Schrader and Fenner, 1976: pl. 1, figs. $3-5,12,15-18$.
Nitzschia riedelia Schrader, 1974: p. 549, figs. 6, 20, 21; Schrader and Fenner, 1976, pl. 1, figs. 14, 19

Porosira glacialis (Grunow) Jørgensen, 1905; Schrader and Fenner, 1976, pl. 16, figs. 1-4; pl. 197, fig. 1.

Proboscia alata Sundström, 1986: p. 99-102, pl. 36, figs. 258-266; synonym: Rhizosolenia alata Brightwell, 1858, p. 95, pl. 5, figs. 8, 8a.

Proboscia barboi Jordan and Priddle, 1991: p. 56; synonym: Rhizosolenia barboi (Brun) Tempére and Peragallo, 1908, p. 26, no. 47; Akiba and Yanagisawa, 1986, p. 497, pl. 42, figs. 3-5, 7, 10, 11; pl. 44, figs. 1-8.

Proboscia curvirostris Jordan and Priddle, 1991: p. 57; synonym: Rhizosolenia curvirostris Jousé 1959, p. 48, pl. 2, fig. 17; Akiba and Yanagisawa, 1986, p. 497, pl. 42, figs. 1, 2; pl. 45, figs. 1-6.

Proboscia praebarboi Jordan and Priddle, 1991: p. 57; synonym: Rhizosolenia praebarboi Schrader, 1973, p. 709, pl. 24, figs. 1-3; Akiba and Yanagisawa, 1986, p. 497, pl. 42, figs. 8, 9; pl. 43, figs. 1-9.

Pseudodimerogramma filiformis Schrader and Fenner, 1976: pl. 3, figs. 21, 22.

Pseudopodosira simplex (Jousé) Strelnikova, 1974: p. 51-52, pl. 2, figs. 10, 11; Schrader and Fenner, 1976, pl. 12, figs. 24, 25.

Pseudopyxilla directa (Pantocsek) Forti, 1909: p. 13; Schrader and Fenner, 1976, pl. 9, figs. 8, 9; pl. 44, fig. 12.

Pseudopyxilla rossica (Pantocsek) Forti, 1909: pl. 1, fig. 13; Schrader and Fenner, 1976, pl. 12, figs. 19, 20; pl. 44, figs. 2, 4, 5 .

Pterotheca aculeifera Grunow, 1880; Schrader and Fenner, 1976, pl. 43, figs. 1-4; Baldauf, 1984, pl. 10, figs. 11, 12.

Pterotheca reticulata Sheshukova-Poretzkaya, 1967: p. 229, pl. 36, fig. 6a-c; pl. 8, fig. 4a-c; Schrader and Fenner, 1976, pl. 12, figs. 1, 2, 11; pl. 38, figs. $10-12,14-16$; pl. 45 , fig. 6 .

Rhaphoneis margaritalimbata Mertz, 1966: p. 27, pl. 6, figs. 1-3; Schrader and Fenner, 1976, pl. 5, figs. 23, 24.

Rhaphoneis ossiformis Schrader in Schrader and Fenner, 1976: pl. 5, fig. 20.

Rhaphoneis parallelica Schrader and Fenner, 1976: pl. 5, figs. 15-19.

Rhizosolenia bergonii Peragallo, 1892: p. 110, pl. 15, fig. 5; Schrader and Fenner, 1976, pl. 41, fig. 14;

Rhizosolenia hebetata forma hebetata Sundström, 1986: p. 47, 48, pl. 4, figs. $18 \mathrm{a}$, b; pl. 17, figs. 112,113 .

Rhizosolenia hebetata forma semispina (Hensen) Gran, 1904: p. 524, pl. 17; Sundström, 1986, p. 48-52, pl. 4, figs. 19, 20; pl. 17, figs. 117, 118.

Rhizosolenia miocenica Schrader, 1973: p. 709, pl. 10, figs. 2-6, 9-11; Schrader and Fenner, 1976, pl. 9, figs. 5, 11, 13, 14

Rhizosolenia norwegica Schrader in Schrader and Fenner, 1976: pl. 9, figs. 4, 10.

Rhizosolenia styliformis Brightwell, 1858: p. 95, pl. 5, figs. 5a, b, d; Baldauf, 1987, pl. 6, fig. 7.

Stellarima microtrias (Ehrenberg) Hasle and Sims, 1986: 111; Hasle, Sims and Syvertsen, 1988, figs. 1-25.

Stephanogonia hanzawae Kanaya, 1959: p. 118-119, pl. 11, figs. 3-7, Schrader and Fenner, 1976, pl. 12, figs. 10, 12; pl. 13, figs. 5, 7, 8.

Stephanopyxis spinossima Grunow, 1884: p. 90-91; Schrader and Fenner, 1976, pl. 31, fig. 5; Dzinoridze et al., 1978, pl. 14, fig. 7.

Stephanopyxis turris (Greville and Arnott) Ralfs in Pritchard, 1861: p. 826, pl. 5, fig. 74; Schrader and Fenner, 1976, pl. 30, figs. 1-10, 14; pl. 37, figs. 17-19.

Synedra miocenica Schrader, 1976: p. 94, pl. 1, fig. 1; Schrader and Fenner, 1976, pl. 5, fig. 2; pl. 45, figs. 19-21.

Synedra pulchella (Ralfs) Kützing, 1844; Hustedt, 1930, p. 191-192, fig. 688; Schrader and Fenner, 1976, pl. 5, figs. 10, 11.

Thalassionema lineatum Jousé, 1971: p. 15-16, fig. 3; Schrader and Fenner, 1976, pl. 5, figs. 5,9 .

Thalassionema nitzschioides (Grunow) Van Heurck, 1896: p. 319, fig. 75; Schrader and Fenner, 1976, pl. 5, fig. 8.

Thalassiosira anguste-lineata (A. Schmidt) Fryxell and Hasle, 1977: p. 73, figs. 22-34.

Thalassiosira baldaufii Bodén, 1993: p. 9-10, pl. 1, figs. R-V; pl. 2, figs. AG; pl. 4, fig. A.

Thalassiosira convexa Muchina, 1965: p. 22, pl. 11, figs. 1-2; Baldauf, 1987. pl. 2, fig. 5; Bodén, 1992, pl. 4, fig. 2.

Thalassiosira decipiens (Grunow) Jørgensen, 1905; Hustedt, 1930, p. 322 323, fig. 158; Schrader and Fenner, 1976, pl. 17, fig. 9.

Thalassiosira eccentrica (Ehrenberg) Cleve, 1904; Fryxell and Hasle, 1972, p. 300 , pl. 1, figs. 1a-2; pl. 2, figs. 3-10; pl. 3, figs. 11-15; pl. 4, figs. 1618.

Thalassiosira gravida Cleve, 1896: p. 12, pl. 2, figs. 14-16; Hustedt, 1928, p. 325, fig. 161; Schrader and Fenner, 1976, pl. 16, figs. 5, 6; pl. 17, fig. 2. 
Thalassiosira grunowii Akiba and Yanagisawa, 1986: p. 493, pl. 27, fig. 5, pl. 29 , figs. $1-8 \mathrm{~b}$, pl. 30 , figs. 1-10; synonym: Coscinodiscus plicatus Grunow, 1878 in Schmidt et al. (1874-1959): pl. 59, fig. 1; Schrader and Fenner, 1976, pl. 15, figs. 5, 8, 9, 11-13.

Thalassiosira jacksonii Koizumi and Barron in Koizumi, 1980: p. 396, pl. 1, figs. 11-14; Baldauf, 1984, pl. 5, fig. 11; Bodén, 1992: pl. 5, figs. 7a-b. Synonym: Thalassiosira sp. b Schrader and Fenner, 1976, pl. 17, figs. 5, 10.

Thalassiosira kryophila (Grunow) Jørgensen, 1905; Hustedt, 1930, p. 324 325 , fig. 160 .

Thalassiosira nidulus (Tempére and Brun) Jousé, 1961: p. 63; Schrader and Fenner, 1976, pl. 17, figs. 13, 16 .

Thalassiosira nordenskioeldii Cleve, 1873: p. 7, pl. 1, fig. 11; Hustedt, 1928, p. 321, fig. 157; Sancetta, 1982, p. 242, pl. 5, figs. 8-9.

Thalassiosira oestrupii (Ostenfeld) Proshkina-Lavrenko; Hasle, 1960, p. 8, pl. 1, figs. 5-7; Akiba, 1986, pl. 14, figs. 1-6.
Thalassiosira sp. a. Schrader and Fenner, 1976, pl. 17, fig. 17.

Thalassiosira sp. c. Schrader and Fenner, 1976, pl. 16, figs. 7, 8.

Thalassiosira trifulta Fryxell in Fryxell and Hasle, 1979: p. 16, pls. 1-5, figs. 1-24; Sancetta, 1982, p. 244, pl. 5, figs. 10-12.

Thalassiosira yabei (Kanaya) Akiba and Yanagisawa, 1986: p. 493, pl. 27, figs. 1-2, pl. 28, figs. 1-9; synonym: Coscinodiscus yabei Kanaya, 1959: p. 86, pl. 5, figs. 6-9; Schrader, 1973 , p. 704 , pl. 6, figs. 1-6.

Thalassiosira zabelinae Jousé, 1961: p. 66, pl. 2, figs. 1-7; Akiba, 1986, pl. 8 , fig. 11 .

Thalassiothrix longissima Cleve and Grunow, 1880: Hustedt, 1932, p. 247, fig. 726; Hasle and Semina, 1987, figs. 1-25.

Thalassiothrix miocenica Schrader, 1973: p. 713, pl. 23, figs. 2-5, Schrader and Fenner, 1976, pl. 5, fig. 1; Bodén, 1992, pl. 1. fig. 1. 


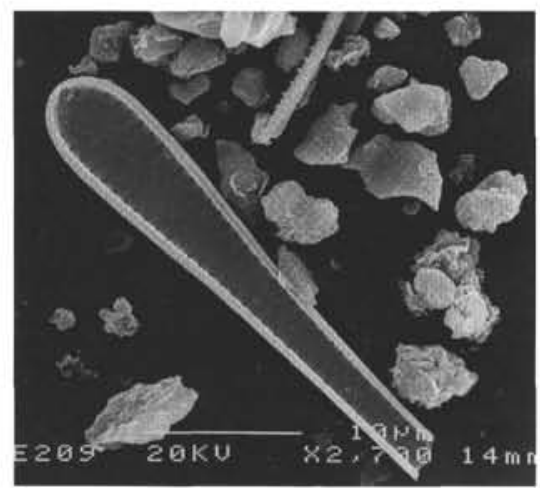

1

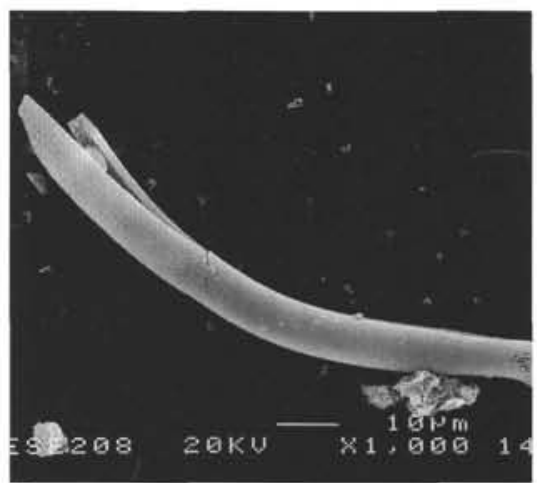

4

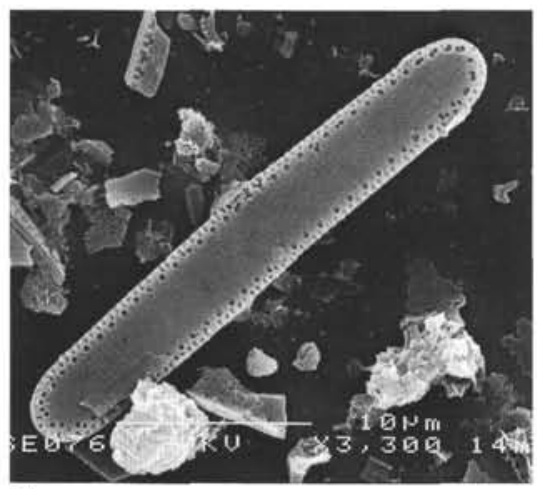

7

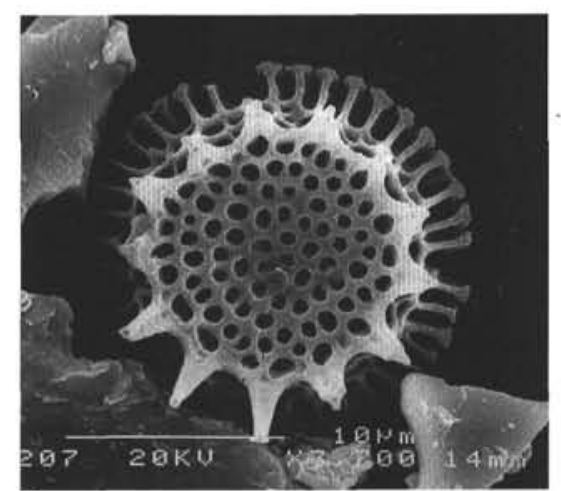

2

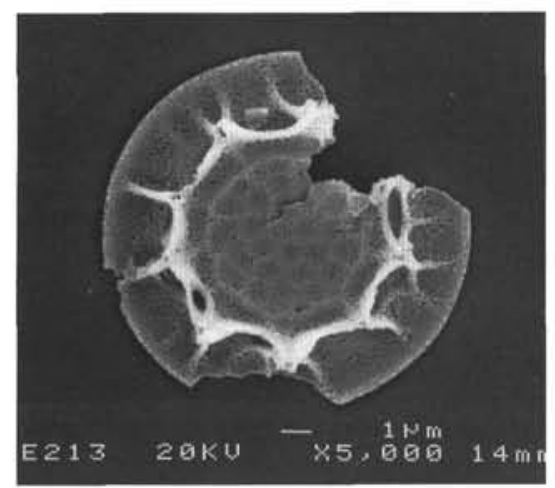

5

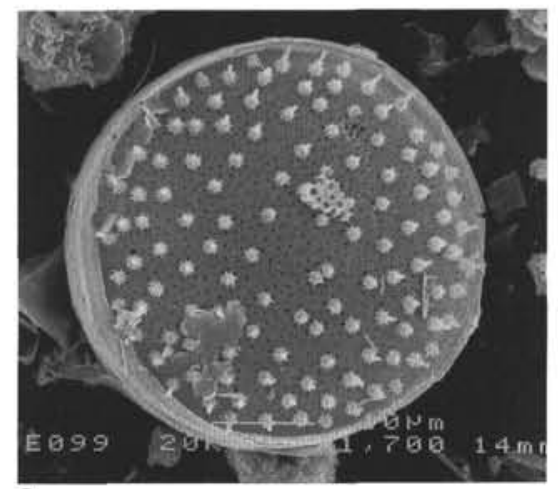

8

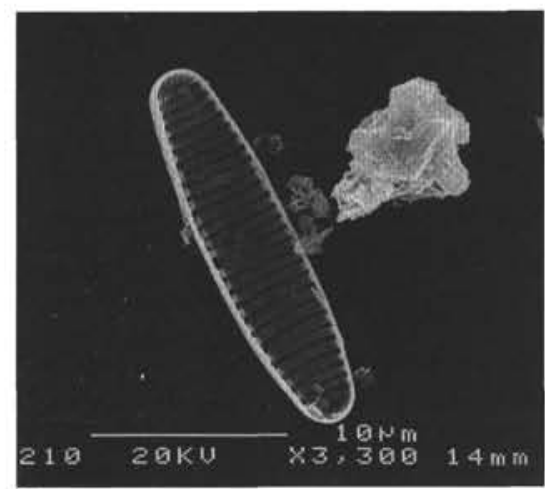

3

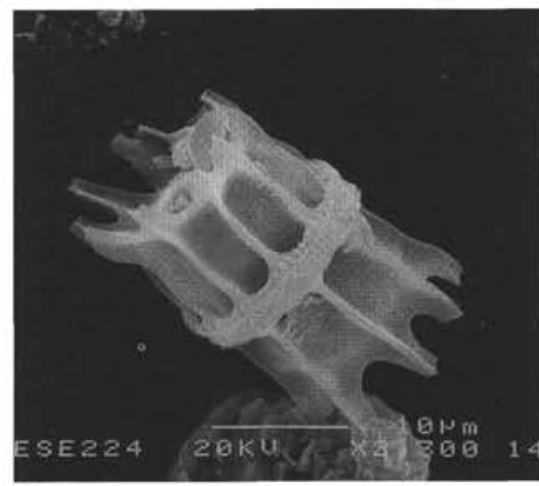

6

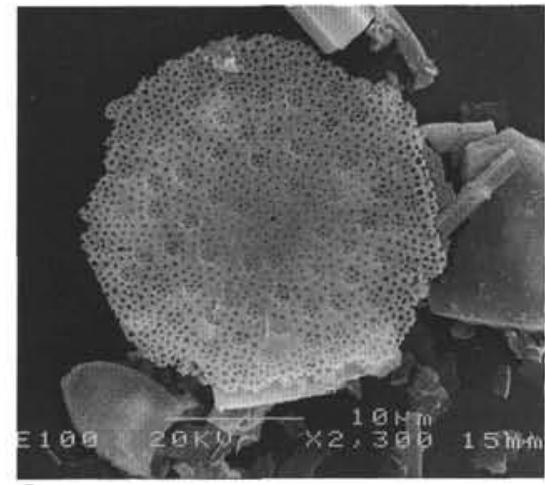

9

Plate 1. Scale bar $=10 \mu \mathrm{m}$, unless otherwise indicated. 1. Thalassiothrix miocenica Schrader, SEM, internal view of valve face, Sample 151-907A-8H-1, 64-65 $\mathrm{cm}$. 2. Thalassiosira nidulus Jousé, SEM, external view of valve face, Sample 151-907A-8H-1, 64-65 cm. 3. Nitzschia pseudocylindrica Schrader, SEM, internal view of valve face, Sample 151-907A-8H-CC. 4. Proboscia barboi Jordan and Priddle, SEM, Sample 151-907A-8H-1, 64-65 cm. 5-6. Stephanogonia hanzawae Kanaya, SEM, (5) valve view, Sample 151-907A-8H-CC, (6) girdle view, Sample 151-907A-10H-3, 98-100 cm. 7. Thalassionema lineatum Jousé, SEM, external view of valve face, Sample 151-907A-14H-4, 72-73 cm. 8-9. Coscinodiscus norwegicus Schrader, SEM, (8) internal view of valve face, (9) external view of valve face, Sample 151-907A-16H-CC. 


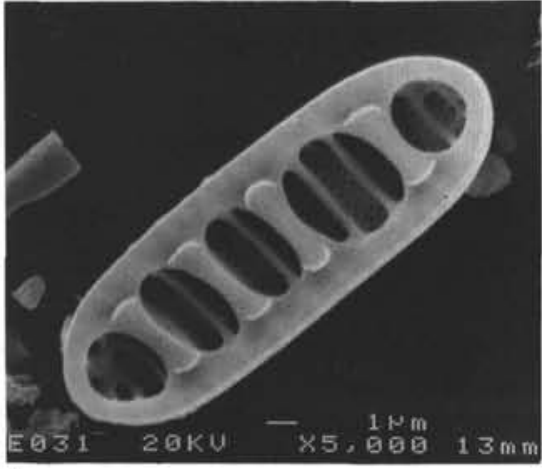

1

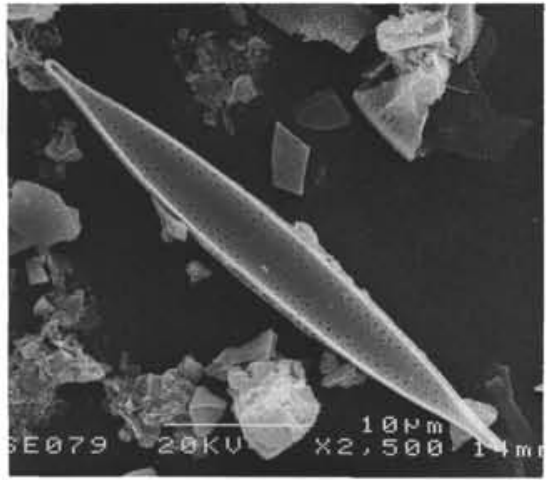

4

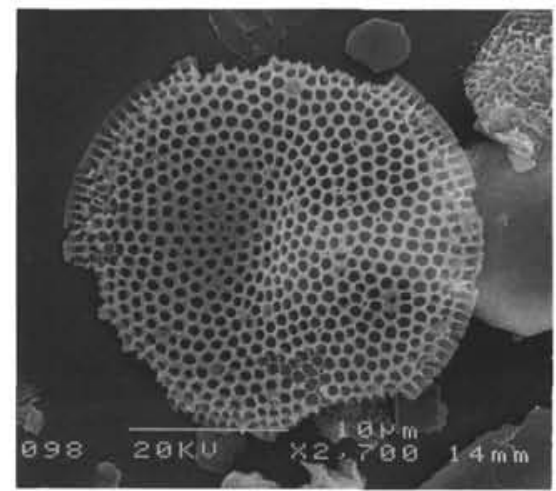

7

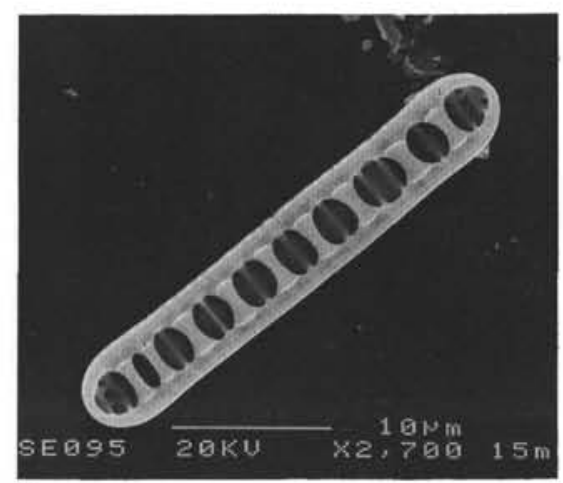

2

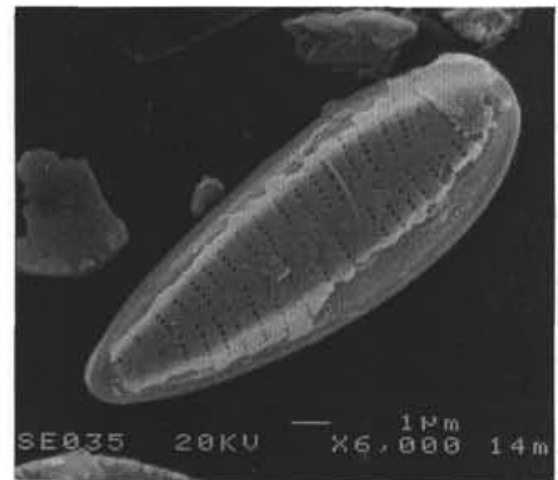

5

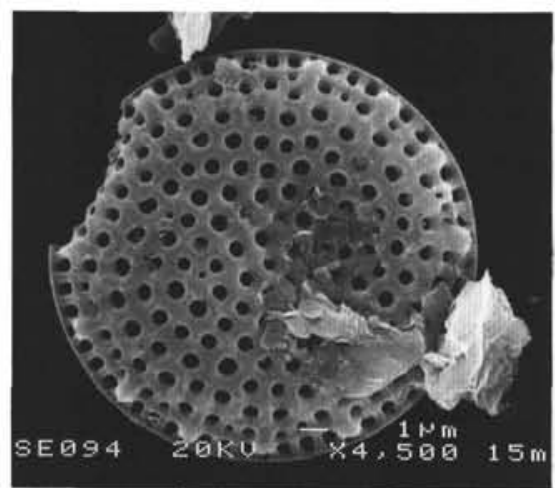

8

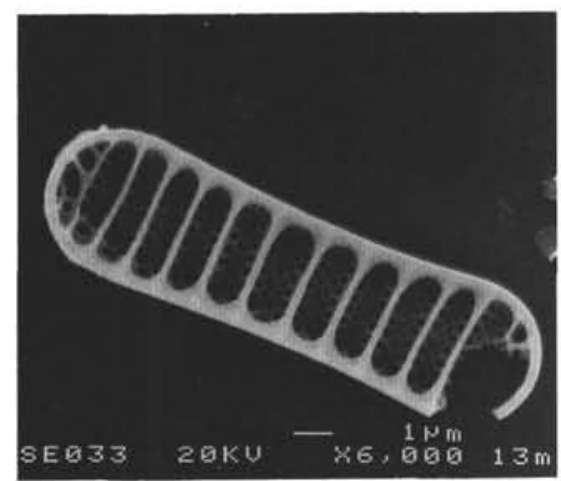

3

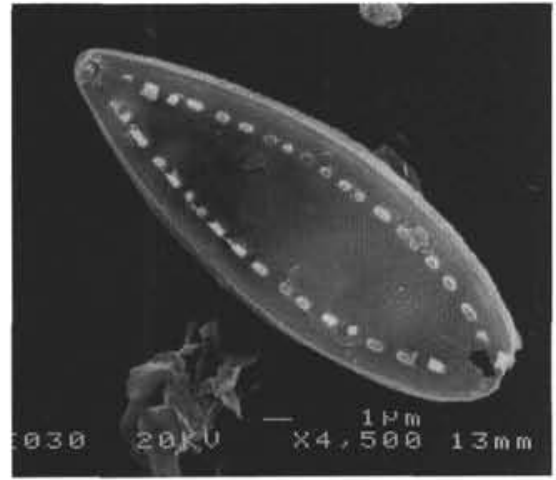

6

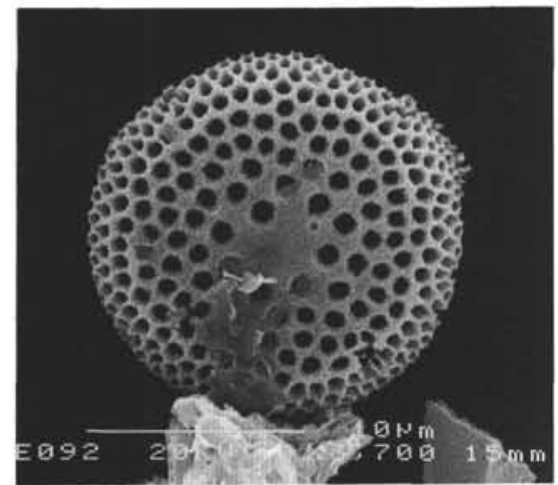

9

Plate 2. Scale bar $=10 \mu \mathrm{m}$, unless otherwise indicated. 1-2. Denticulopsis hustedtii Simonsen, SEM, internal views of valve face, (1) Sample 151-907A-18H-3, 83-84 cm, (2) Sample 151-907A-16H-CC. 3. Denticulopsis praedimorpha Barron, SEM, internal view of valve face, Sample 151-907A-18H-3, 83-84 cm. 4. Cymatosira biharensis Pantocsek, SEM, internal view of valve face, Sample 151-907A-14H-4, 72-73 cm. 5-6. Ikebea tenuis (Brun) Akiba, SEM, (5) external view of valve face, Sample 151-907A-19H-CC, (6) internal view of valve face, Sample 151-907A-18H-3, 83-84 cm. 7. Thalassiosira grunowii Akiba and Yanagisawa, SEM, external view of valve face, Sample 151-907A-16H-CC. 8. Thalassiosira yabei (Kanaya) Akiba and Yanagisawa, SEM, external view of valve face, Sample 151-907A-16H-CC. 9. Actinocyclus ingens Rattray, SEM, external view of valve face, Sample 151-907A-16H-CC. 


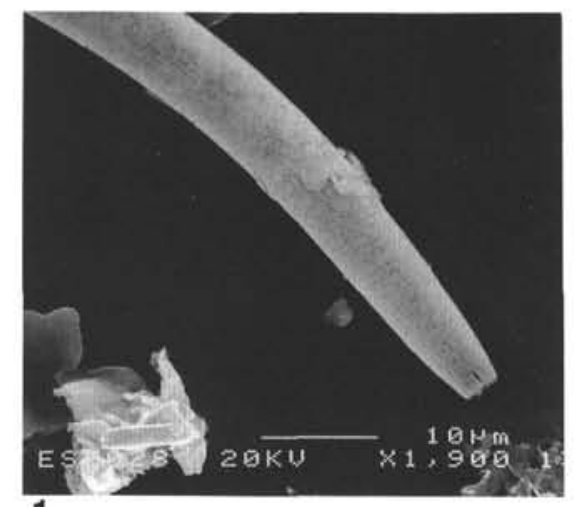

1

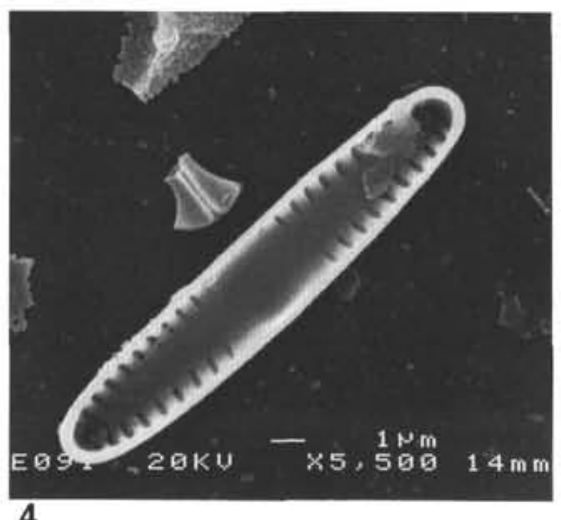

4

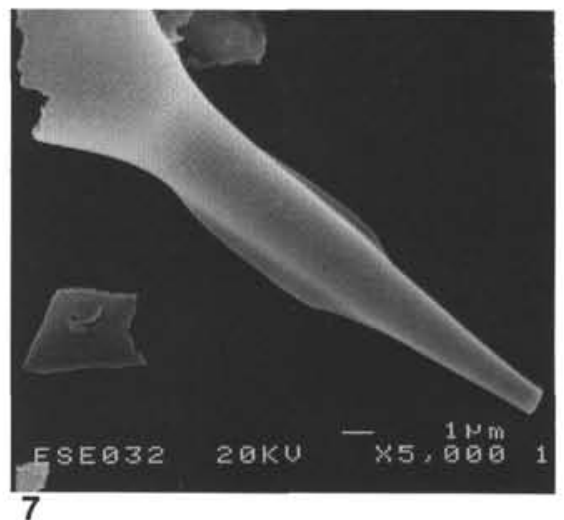

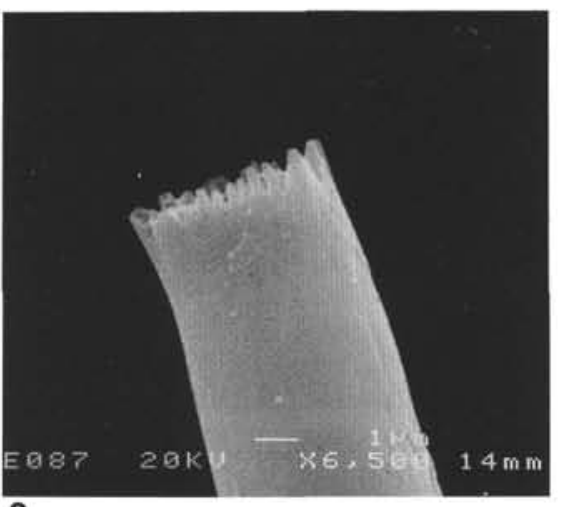

2

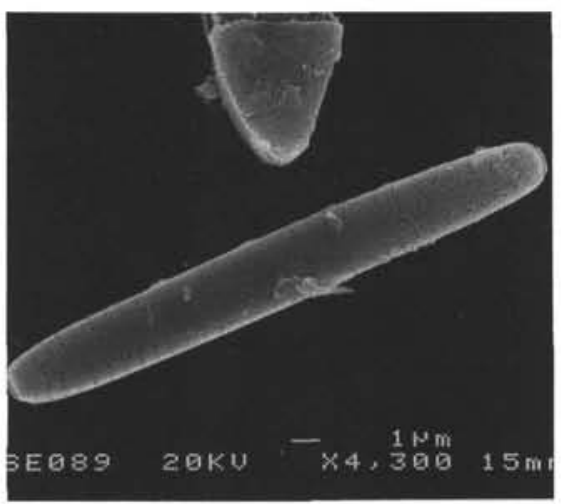

5

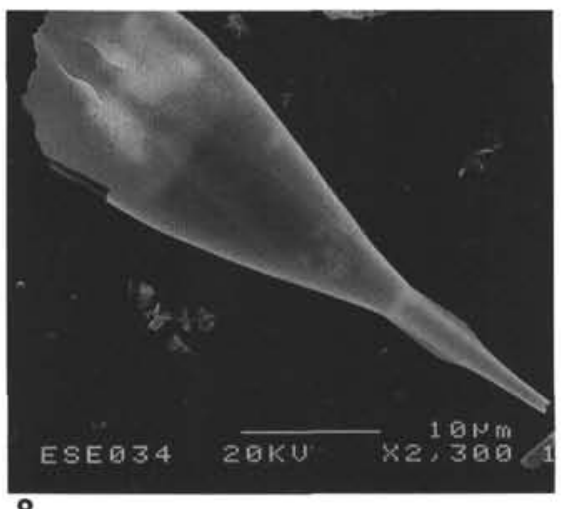

8

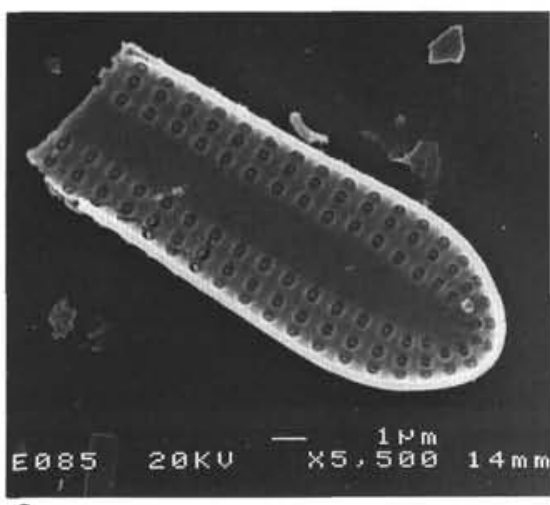

3

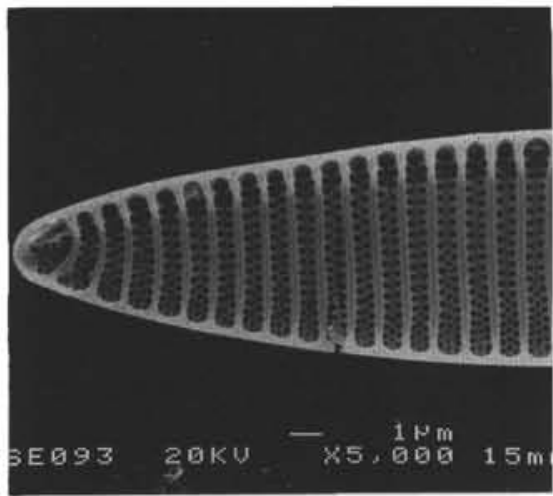

6

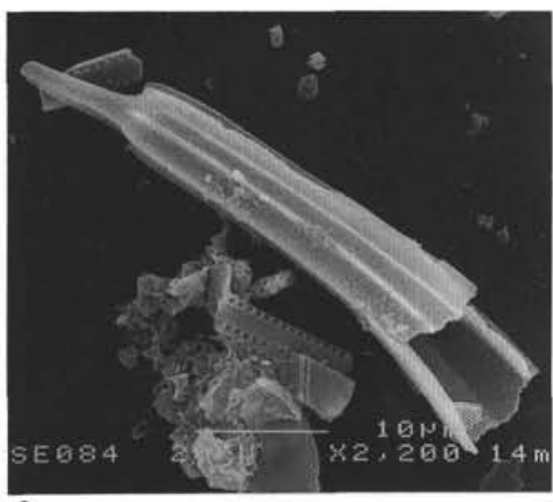

9

Plate 3. Scale bar $=10 \mu \mathrm{m}$, unless otherwise indicated. 1-2. Proboscia praebarboi Jordan and Priddle, SEM, (1) Sample 151-907A-18H-3, 83-84 cm. (2) Close-up view of the distal end, Sample 151-907A-15H-5, 106-107 cm. 3. Rhaphoneis ossiformis Schrader, SEM, internal view of valve face, Sample 151907A-14H-4, 72-73 cm. 4-5. Synedra pulchella (Ralfs) Kützing, SEM, (4) internal view of valve face, (5) external view of valve face, Sample 151-907A-15H5, 106-107 cm. 6. Nitzschia donahuensis Schrader, SEM, Sample 151-907A-16H-CC. 7-8. Rhizosolenia norwegica Schrader, SEM, Sample 151-907A-18H-3, 83-84 cm. 9. Rhizosolenia miocenica Schrader, SEM, Sample 151-907A-14H-4, 72-73 cm. 